\title{
Atypical McMurry Cross-Coupling Reactions Leading to a New Series of Potent Antiproliferative Compounds Bearing the Key [Ferrocenyl-Ene-Phenol] Motif
}

\author{
Pascal Pigeon ${ }^{1,2}$, Meral Görmen ${ }^{1}$, Konrad Kowalski ${ }^{3}$, Helge Müller-Bunz ${ }^{4}$, \\ Michael J. McGlinchey ${ }^{4}$, Siden Top ${ }^{2, *}$ and Gérard Jaouen ${ }^{1,2, *}$
}

1 Chimie ParisTech, 11 rue Pierre et Marie Curie, Paris F75231 Paris cedex 05, France; E-Mails: pascal.pigeon@chimie-paristech.fr (P.P.); meralgormen@gmail.com (M.G.)

2 Sorbonne Universités, UPMC univ Paris 6, Institut Parisien de Chimie Moléculaire (IPCM) - UMR 8232, 4 place Jussieu, 75252 Paris Cedex 05, France

3 Faculty of Chemistry, Department of Organic Chemistry, University of Łódź, Tamka 12, 91-403 Łódź, Poland; E-Mail: konkow@chemia.uni.lodz.pl

4 UCD School of Chemistry and Chemical Biology, University College Dublin, Belfield, Dublin 4 Ireland ; E-Mails: helge.muellerbunz@ucd.ie (H.M.-B.); michael.mcglinchey@ucd.ie (M.J.M.)

* Authors to whom correspondence should be addressed; E-Mails: siden.top@upmc.fr (S.T.); gerard.jaouen@upmc.fr (G.J.); Tel.: +33-1-44-27-66-99 (S.T.); +33-1-43-26-95-55 (G.J.); Fax: +33-1-43-26-00-61 (S.T.); +33-1-43-26-00-61 (G.J.).

Received: 12 June 2014; in revised form: 3 July 2014 / Accepted: 7 July 2014 / Published: 17 July 2014

\begin{abstract}
In the course of the preparation of a series of ferrocenyl derivatives of diethylstilbestrol (DES), in which one of the 4-hydroxyphenyl moieties was replaced by a ferrocenyl group, the McMurry reaction of chloropropionylferrocene with a number of mono-aryl ketones unexpectedly yielded the hydroxylated ferrocenyl DES derivatives, 5a-c, in poor yields $(10 \%-16 \%)$. These compounds showed high activity on the hormone-independent breast cancer cell line MDA-MB-231 with $\mathrm{IC}_{50}$ values ranging from 0.14 to $0.36 \mu \mathrm{M}$. Surprisingly, non-hydroxylated ferrocenyl DES, 4 , showed only an $\mathrm{IC}_{50}$ value of $1.14 \mu \mathrm{M}$, illustrating the importance of the hydroxyethyl function in this promising new series. For comparison, McMurry reactions of the shorter chain analogue chloroacetylferrocene were carried out to see the difference in behaviour with mono-aryl ketones versus a diaryl ketone. The effect of changing the length of the alkyl chain adjacent to the phenolic substituent of the hydroxylated ferrocenyl DES was studied, a mechanistic rationale to account for the unexpected products is proposed, and the
\end{abstract}


antiproliferative activities of all of these compounds on MDA-MB-231 cells lines were measured and compared. X-ray crystal structures of cross-coupled products and of pinacol-pinacolone rearrangements are reported.

Keywords: DES; ferrocene; pinacol rearrangement; McMurry reaction; antiproliferative activity; MDA-MB-231

\section{Introduction}

Bioorganometallic chemistry, otherwise known as organometallic chemical biology, a field that encompasses organometallics in biology and medicine, is one of the fastest growing fields. Indeed, many organo-transition metal complexes have attracted great interest in a wide range of medicinal areas [1-7]. As part of our programme to study ferrocene derivatives with anticancer properties, we have previously reported that ferrocidiphenol $\left(4-\mathrm{HO}-\mathrm{C}_{6} \mathrm{H}_{4}\right)_{2} \mathrm{C}=\mathrm{C}(\mathrm{Et}) \mathrm{Fc}, 1$, [8,9] shows an effective cytostatic effect $\left(\mathrm{IC}_{50}=0.7 \mu \mathrm{M}\right.$ on hormone-dependent $\mathrm{MCF}-7$ and $\mathrm{IC}_{50}=0.6 \mu \mathrm{M}$ on hormone-independent MDA-MB-231 breast cancer cell lines) [10]. We chose to prepare this antiproliferative species, modelled on tamoxifen (TAM), but lacking the aminoalkyl chain which is irrelevant for the MDA-MB-231 cell line devoid of the estrogen $\alpha$ receptor (ER $\alpha$ ). Toremifene (TOR, Scheme 1), a chlorinated derivative of tamoxifen, is an effective and well-tolerated agent for the therapy of postmenopausal women with hormonal positive receptor advanced breast cancer [11-14]. Its citrate form is approved by the FDA and licensed in the United States under the brand name Fareston $^{\circledR}$. TOR is considered as an alternative to TAM as a first line therapy for ER+ advanced breast cancer patients, and also as an adjuvant treatment [15]. It decreases the incidence of prostate cancer in men with high grade prostatic intraepithelial neoplasia [16,17]. It also shows a benefit by increasing hip and spine bone mineral density in men receiving androgen deprivation therapy for prostate cancer [18]. By analogy to the structure of TOR, in which TAM has been modified by incorporation of a chloroethyl substituent, we synthesized $\mathbf{2}$, the chloroethyl derivative of ferrocidiphenol, $\mathbf{1}$, and found it to have low antiproliferative activity against MCF-7 and moderate activity on MDA-MB-231 $\left(\mathrm{IC}_{50}=1 \mu \mathrm{M}\right)$. This led us to postulate that a hydrophobic substituent on the ethyl group diminishes the antiproliferative efficiency. We have also previously suggested that, to be active, the redox-active ferrocifen complexes need to possess the key [ferrocenyl-ene-phenol] motif, to allow in vivo formation of an electrophilic quinone methide that we supposed to be the active metabolite [19].

Accordingly, we envisioned the synthesis of a series of new compounds having the minimum structural requirement for efficiency, i.e., bearing only one hydroxyphenyl group. We chose also to replace the second phenolic group in $\mathbf{1}$ and $\mathbf{2}$ by an ethyl group, thus leading to a series of ferrocenyl complexes analogous to diethylstilbestrol (DES). Diethylstilbestrol, [(E)-3,4-[bis-(4'-hydroxyphenyl)3-hexene], acts as a powerful estrogen via ER $\alpha$ and ER $\beta$ [20]. This compound was prescribed for the prevention of pregnancy complications, but was subsequently prohibited due to many adverse effects, including carcinogenicity and teratogenicity [21], increased incidence of reproductive and genital abnormalities [22]. We have previously reported the synthesis of organochromium complexes of hexestrol, a hydrogenated version of DES [23,24], and ferrocenyl derivatives of estradiol and of 
hexestrol are also known [25]. In this new series, our goal was to compare the effect of chloroethyl (as in compound 3b) and ethyl (as in compound 4) groups on the antiproliferative activity of these compounds, as had been done previously for molecules 1 and 2 [26].

Somewhat surprisingly however, attempts to prepare the aforementioned chlorinated compounds, via McMurry coupling of chloropropionylferrocene and 4-hydroxyphenyl-alkyl ketones of varying alkyl chain length, led instead to hydroxyethyl derivatives $(\mathbf{5 a}-\mathbf{c})$ resulting from the replacement of chlorine atom by a hydroxyl group; in addition, compounds resulting from pinacol-to-pinacolone rearrangement were also isolated. We here report the results of these atypical McMurry coupling reactions, and make comparison with the more usual reactions seen when using 4,4'dihydroxybenzophenone as the purely organic ketone counterpart.

Scheme 1. Toremifene, ferrocidiphenol, ClFcdiOH, DES and the new Fc-DES series.

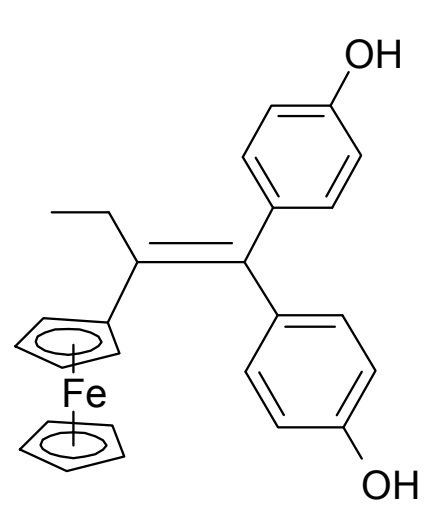

Ferrocidiphenol

(FcdiOH) 1

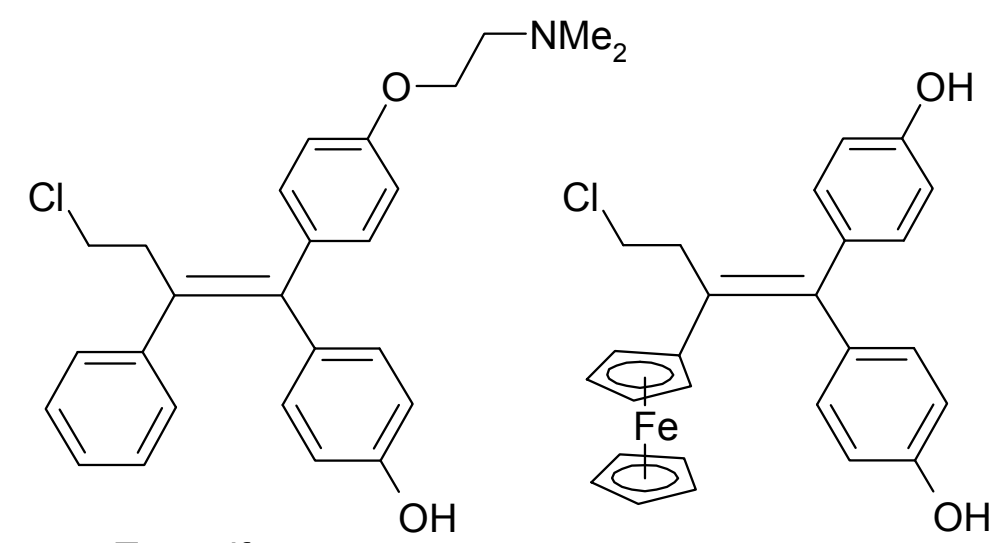

ClFcdiOH 2

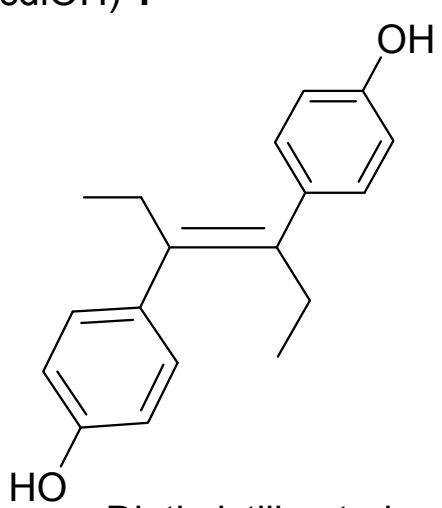

Diethylstilbestrol

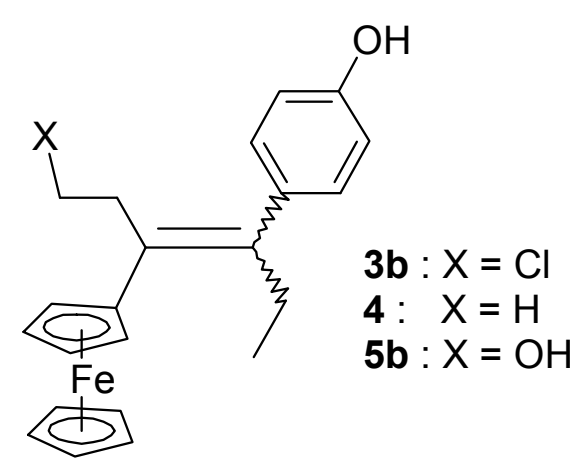

Ferrocenyl analogues

\section{Results and Discussion}

\subsection{Synthetic Aspects}

Following the synthetic procedure successfully used for $\mathbf{2}$, the chloroethyl derivative of ferrocidiphenol, 1 [26], we first performed a McMurry coupling between chloropropionylferrocene, 6 [27], and 4-hydroxypropiophenone, $\mathbf{7 b}$ (Scheme 2). Surprisingly, only the hydroxyl compound $\mathbf{5 b}$ was isolated, albeit in low yield (16\%). The crude oil showed a mixture of inseparable compounds, $\mathbf{5} \mathbf{b}$ being the only compound isolated by chromatographic techniques in pure form. This was attributable to its higher polarity induced by the hydroxyl group, as compared to the other by-products. Moreover, the expected chlorinated 
compound $\mathbf{3 b}$ could not be detected by mass spectrometry in the reaction mixture. Again, when 4-hydroxypropiophenone, 7b, was replaced by 4-hydroxyacetophenone, 7a, or 4-hydroxybutyrophenone, $\mathbf{7 c}$, in the reaction with chloropropionylferrocene, $\mathbf{6}$, only the hydroxyl compounds $\mathbf{5 a}$ and $\mathbf{5 c}$ were isolated, in yields of $10 \%$ and $15 \%$, respectively. This contrasts with the previously observed reaction of 4,4'-dihydroxybenzophenone, 7e, with 6 that furnished 2 (in $47 \%$ yield) [26] with no formation of hydroxylated compound $\mathbf{5 e}$.

Scheme 2. McMurry coupling reactions of chloropropionylferrocene, 6. Two isomers, $Z$ and $E$, were formed, and the designation $E$ refers to the isomer whereby the ferrocenyl group is trans relative to the phenol.

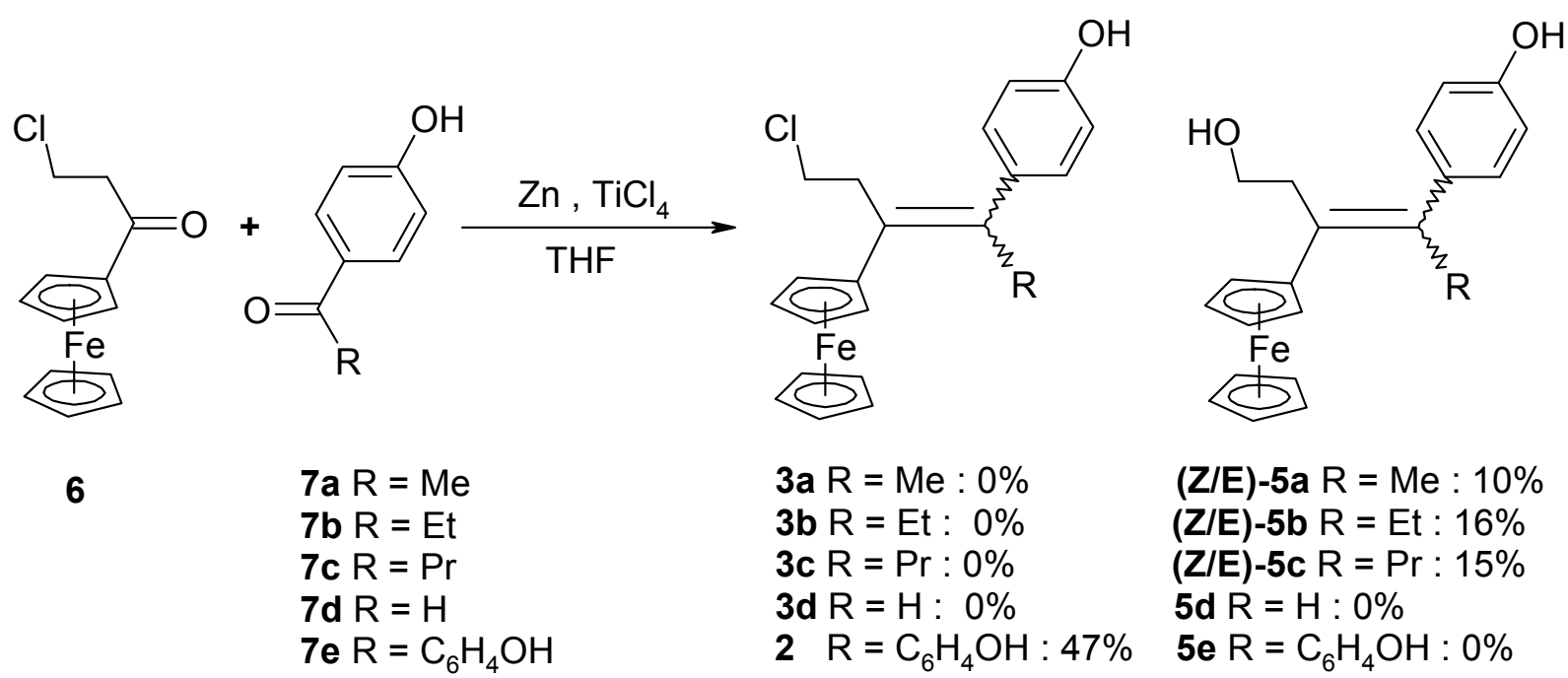

These observations are apparently specific to the McMurry reaction between $\mathbf{6}$ and mono-aryl ketones, since the exchange of chlorine to hydroxyl was found only in these cases. The difference is almost certainly not a steric effect, although electronic effects such as $\pi$-stacking between a hydroxyphenyl group and the ferrocenyl moiety during the formation of the intermediate pinacolate [28] may play a role. The lower yields of cross-coupled product when using mono-aryl ketones $\mathbf{7 a - c}$ with $\mathbf{6}$, rather than the diaryl ketone 7e, may be a result of increased homocoupling and also of pinacol-to-pinacolone rearrangement of intermediate titanium pinacolates. It is known that in McMurry reactions with two mono-aryl ketones there is less selectivity for cross-coupling than when using species as different as a mono-aryl and a diaryl-ketone. In our previous studies involving McMurry reactions between a mono-aryl and a diaryl ketone, the cross-coupling yields were generally quite high, homo-coupling was low, and pinacol rearrangement products were barely detectable. However, in the reactions of diaryl ketones and [3] ferrocenophanone [29], or of 4-hydroxybenzoyl-ferrocene and 4-hydroxypropio-phenone 7b [30], rearrangement to pinacolones occurred. Replacement of the ketone by an aldehyde, as in the reaction of 4-hydroxybenzaldehyde, 7d, with 6, led to an inseparable mixture of unknown products, and neither the chlorinated compound $\mathbf{3 d}$ nor the alcohol $\mathbf{5 d}$ was detected by mass spectrometry.

Alcohols 5a-c were obtained as mixtures of $Z / E$ isomers. Even though the two forms could be separated by semi-preparative HPLC, the isomerization in solution did not allow the isolation of pure isomers except in the case of $\mathbf{5 b}$ for which the major isomer could be isolated from crystallization and identified as a $Z$ isomer by $2 \mathrm{D}$ NMR. However, this isomer slowly isomerized in acetone to give an 
86:14 $Z / E$ mixture. In $\mathbf{5 a}$ and $\mathbf{5 c}$, the observed $Z / E$ ratios in acetone were $73 / 27$ and $62 / 38$, respectively. All reactions produced mixtures, and only the hydroxyl compounds could be isolated in pure form, albeit in relatively low yields.

Suitable crystals of the $E$ isomer of 3-ferrocenyl-4-(4-hydroxyphenyl)-1-hydroxy-hex-3-ene, $\mathbf{5 b}$, could be isolated for an X-ray crystallographic study. The molecular structure appears as Figure 1, and reveals that the ferrocenyl moiety is twisted out of the plane of the double bond though $30.5^{\circ}$, whereas the plane of the phenol ring is rotated through $68.6^{\circ}$, making a dihedral angle between the $\mathrm{C}_{5} \mathrm{H}_{4}$ and aryl rings of $81.8^{\circ}$. The ethyl and hydroxyethyl substituents lie on opposite sides of the central plane and make a dihedral angle of $151.6^{\circ}$. Clearly, these orientations minimise steric interactions between the bulky substituents. The cyclopentadienyl rings in $\mathbf{5 b}$ are parallel and are separated by $3.274 \AA$.

Figure 1. Molecular structure of E-3-ferrocenyl-4-(4-hydroxyphenyl)-1-hydroxy-hex-3-ene, 5b. Thermal ellipsoids are shown at $25 \%$. Selected bond distances $(\AA)$ for $\mathbf{5 b}$ : $\mathrm{C}(1)-\mathrm{C}(2)$ $1.339(5), \quad \mathrm{C}(1)-\mathrm{C}(15) \quad 1.506(5), \quad \mathrm{C}(1)-\mathrm{C}(21)$ 1.512(5), $\mathrm{C}(21)-\mathrm{C}(22)$ 1.526(6), $\mathrm{C}(2)-\mathrm{C}(5)$ 1.485(5), C(2)-C(3) 1.531(5), C(3)-C(4) 1.515(5), C(4)-O(1) 1.433(4), C(18)-O(2) 1.377(5), Fe-centroid $\left(\mathrm{C}_{5} \mathrm{H}_{4}\right)$ 1.634, Fe-centroid $\left(\mathrm{C}_{5} \mathrm{H}_{5}\right) 1.640$.

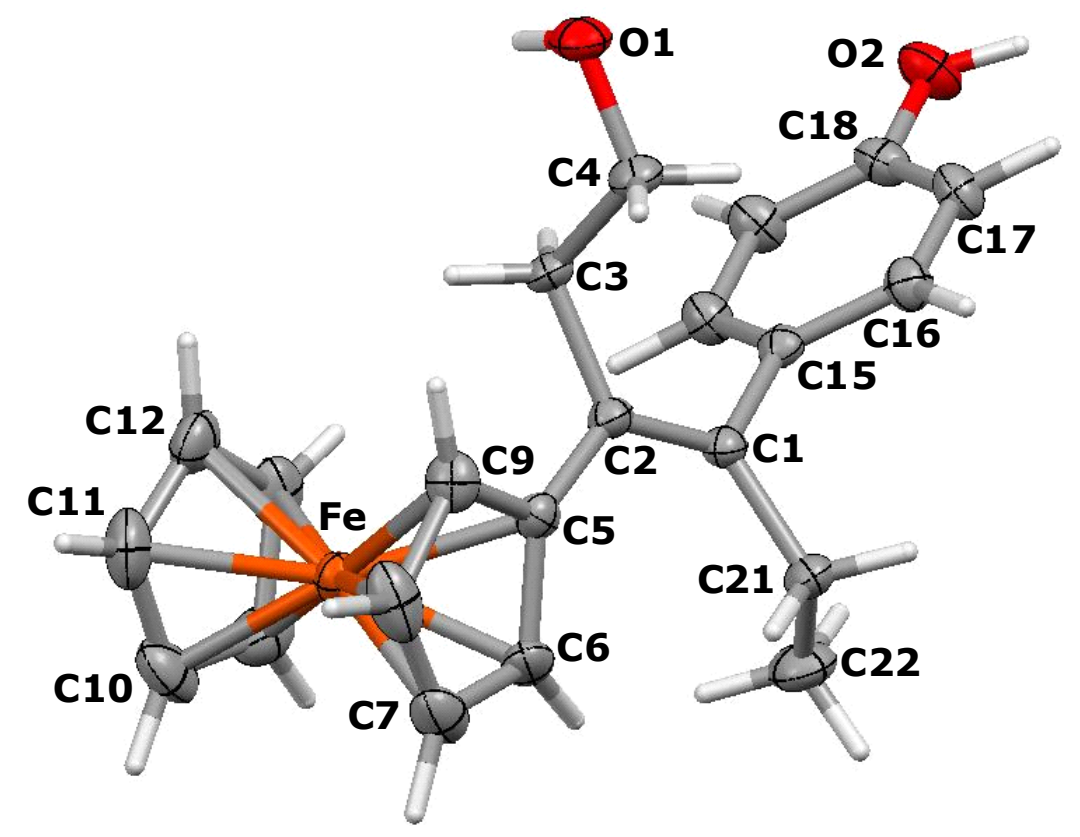

Interestingly, when a shorter chain compound such as chloroacetylferrocene 8 [31] was allowed to react with the mono-aryl ketone $\mathbf{7 b}$, a different process occurred. As shown in Scheme 3, neither of the anticipated ethylenic compounds (chlorinated or hydroxylated) was formed, instead only the dehalogenated pinacolone 9 was isolated, in 29\% yield. This compound corresponds to the formation of the more stable cation, situated $\alpha$ to the ferrocenyl moiety, with subsequent migration of the phenolic group onto the carbon bearing the positive charge. In principle, two pinacol-to-pinacolone rearrangement products are possible, but the migratory aptitude of the phenolic group is markedly higher than that of the alkyl substituent because of the greater ability of the former to delocalize positive charge in the transition state [32]. 
Scheme 3. McMurry reaction between 8 (or 11) and $7 \mathbf{b}$ or $7 \mathbf{e}$.

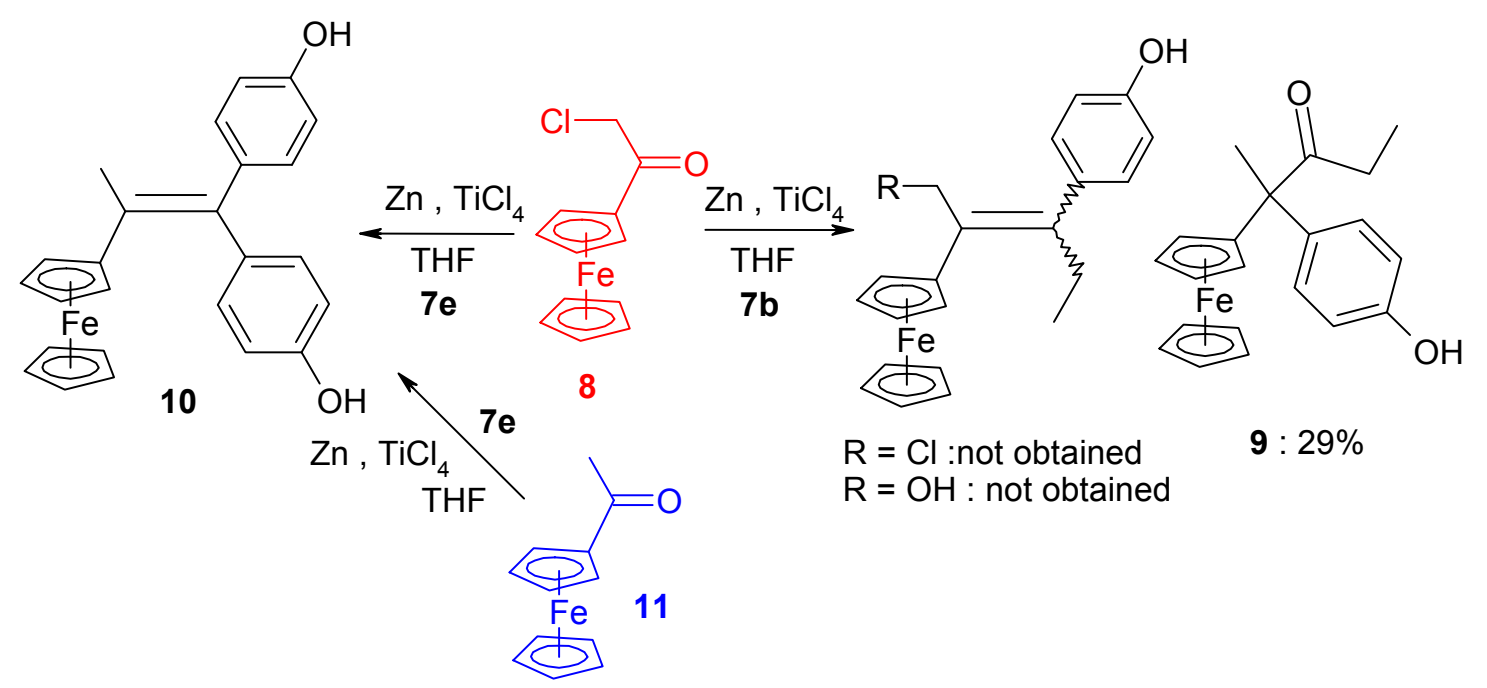

The identity of the pinacolone rearrangement product, $\mathbf{9}$, was determined not only spectro-scopically, but also by X-ray crystallography (Figure 2), which established unequivocally that the phenolic group had migrated onto the carbon atom adjacent to the ferrocenyl substituent. The geometry at the central carbon, $\mathrm{C}(2)$, is almost perfectly tetrahedral with angles ranging only from $109.1^{\circ}$ to $110.2^{\circ}$. The cyclopentadienyl rings in the ferrocenyl unit are parallel, and are separated by $3.331 \AA$; they make a dihedral angle of $85^{\circ}$ with the plane of the phenol.

Figure 2. Molecular structure of 9; thermal ellipsoids are shown at 50\% probability. Selected distances $(\AA)$ : C(11)-C(1) 1.544(3), C(11)-C(18) 1.564(3), C(11)-C(12) 1.546(3), $\mathrm{C}(11)-\mathrm{C}(19)$ 1.550(3), C(19)-C(20) 1.505(4), C(19)-O(2) 1.223(3), C(15)-O(1) 1.376(3), Fe-centroid $\left(\mathrm{C}_{5} \mathrm{H}_{4}\right)$ 1.664, Fe-centroid $\left(\mathrm{C}_{5} \mathrm{H}_{5}\right) 1.667$.

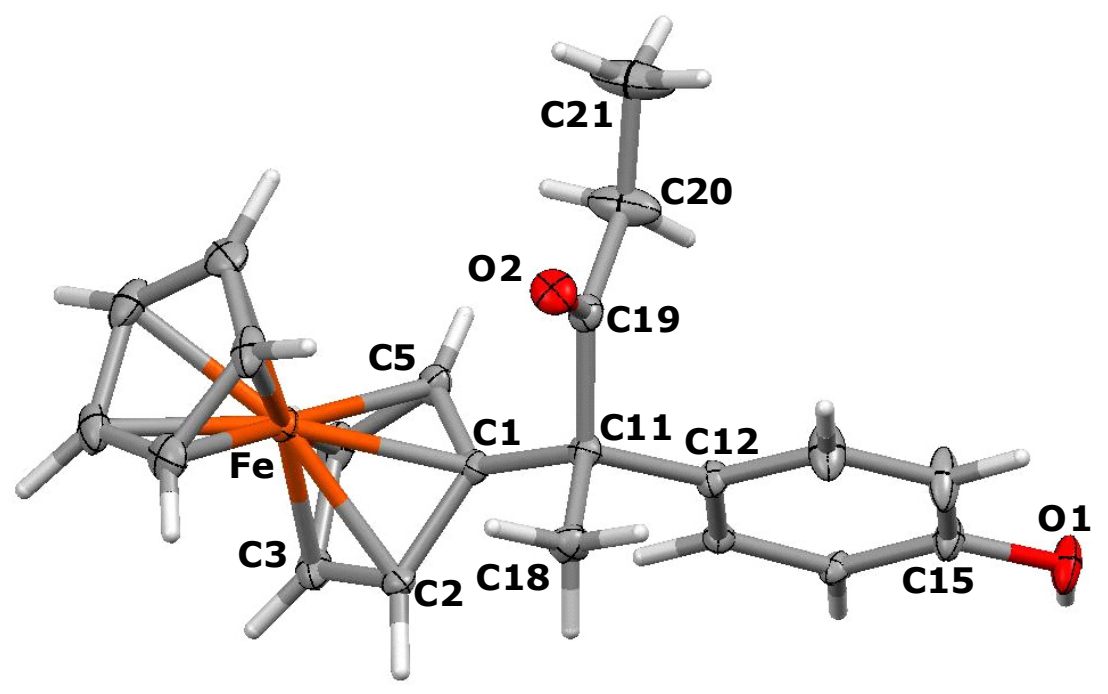

In contrast, the reaction of chloroacetylferrocene, $\mathbf{8}$, and 4,4'-dihydroxybenzophenone, $\mathbf{7 e}$, furnished the alkene 10 (49\%), but no pinacol rearrangement product was observed (Scheme 3). Once again, however, the chlorine atom was replaced by a hydrogen atom, and the identity of $\mathbf{1 0}$ was confirmed by direct coupling of 7e with acetylferrocene, 11; in this latter case, $\mathbf{1 0}$ was obtained in $90 \%$ yield. The 
corresponding reaction between propionylferrocene, $\mathbf{1 2}$, and ketones $\mathbf{7 b}$ or $\mathbf{7 f}$, yielded classical alkenes 4 or 13 in yields of $30 \%$ or $33 \%$, respectively (Scheme 4). The rearrangement products 14 or 15 were also formed as contaminating by-products, and the X-ray crystal structure of 3-ferrocenyl-3-(4hydroxyphenyl)-hexan-4-one, 14, is shown as Figure 3.

Scheme 4. Synthesis of 4 and 13.

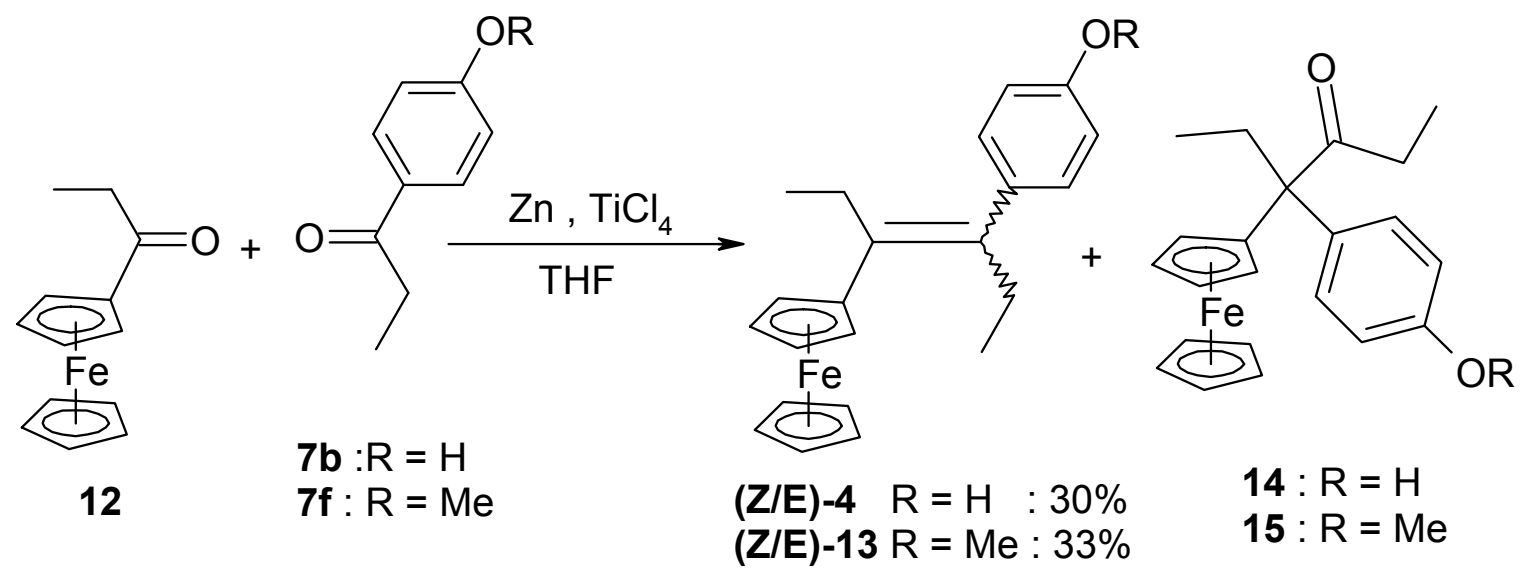

Figure 3. Molecular structure of 3-ferrocenyl-3-(4-hydroxyphenyl)-hexan-4-one, 14.

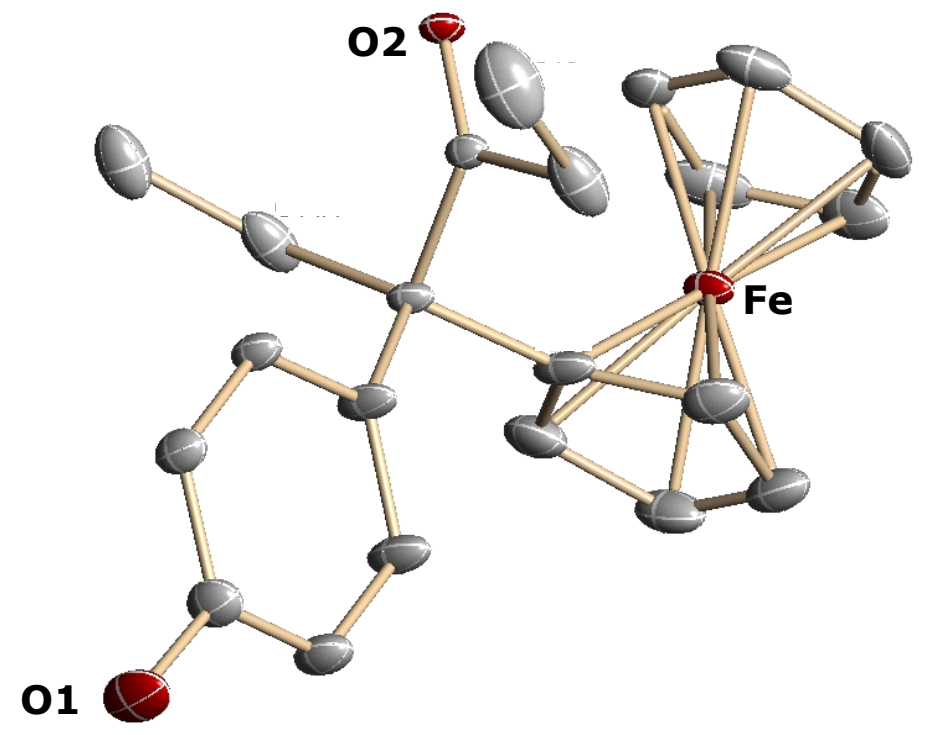

Having shown that alcohols $\mathbf{5 a}-\mathbf{c}$ could be obtained in low yields from the chlorinated precursor $\mathbf{6}$, we sought a more rational route to these compounds. To improve the yield of $\mathbf{5} \mathbf{b}$, we envisioned a McMurry cross-coupling reaction between 4-hydroxypropiophenone, 7b, and ethyl 3-ferrocenyl-3oxo-propanoate, 16 (Scheme 5), with the aim of reducing the ester 17a to the required alcohol $\mathbf{5 b}$. However, McMurry coupling failed to give the desired ester 17a, the only material isolated being the homocoupling product, i.e., diethylstilbestrol (DES), together with recovered unreacted ketoester 16. 
Scheme 5. McMurry reaction between ketoester 16 and mono (7b) and diaryl (7e) ketones.
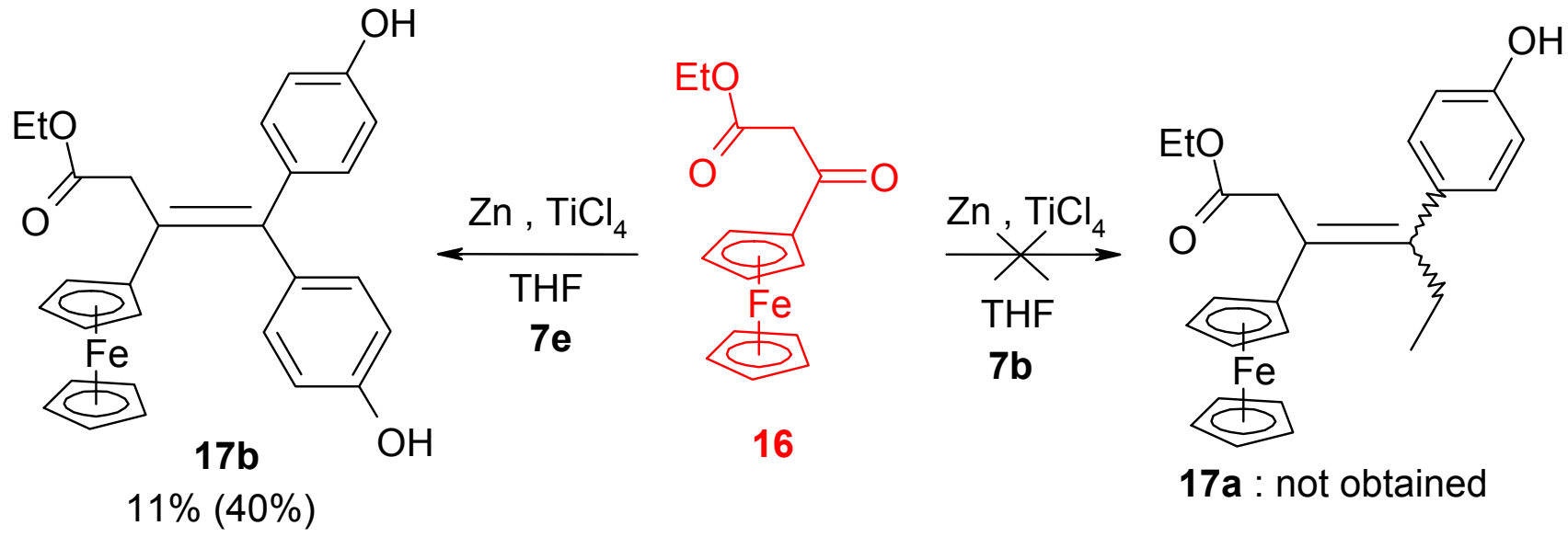

17a : not obtained

In contrast, the reaction of the ketoester $\mathbf{1 6}$ and 4,4'-dihydroxypropiophenone, $\mathbf{7 e}$, led to the alkene $\mathbf{1 7} \mathbf{b}$, but in only $11 \%$ yield, and remaining ketoester was recovered. However, by using two equivalents of 4,4'-dihydroxybenzophenone, the cross-coupling yield could be increased to $40 \%$, allowing the obtention of X-ray quality crystals of $\mathbf{1 7 b}$, whose structure appears as Figure 4.

Figure 4. Molecular structure of ethyl 3-ene-3-ferrocenyl-4,4-bis-(4-hydroxyphenyl)butanoate, 17b. Thermal ellipsoids are shown at 25\%. Selected distances $(\AA)$ : $\mathrm{C}(1)-\mathrm{C}(2)$ 1.3609(17), C(1)-C(15) 1.5048(16), C(1)-C(21) 1.5021(17), C(2)-C(5) 1.4852(16), C(2)-C(3) 1.5273(17), C(3)-C(4) 1.5246(18), C(4)-O(3) 1.3360(16), C(4)-O(4) 1.2255(16), C(18)-O(1) 1.3853(15), C(24)-O(2) 1.3771(16), Fe-centroid $\left(\mathrm{C}_{5} \mathrm{H}_{4}\right)$ 1.662, Fe-centroid $\left(\mathrm{C}_{5} \mathrm{H}_{5}\right)$ 1.667.

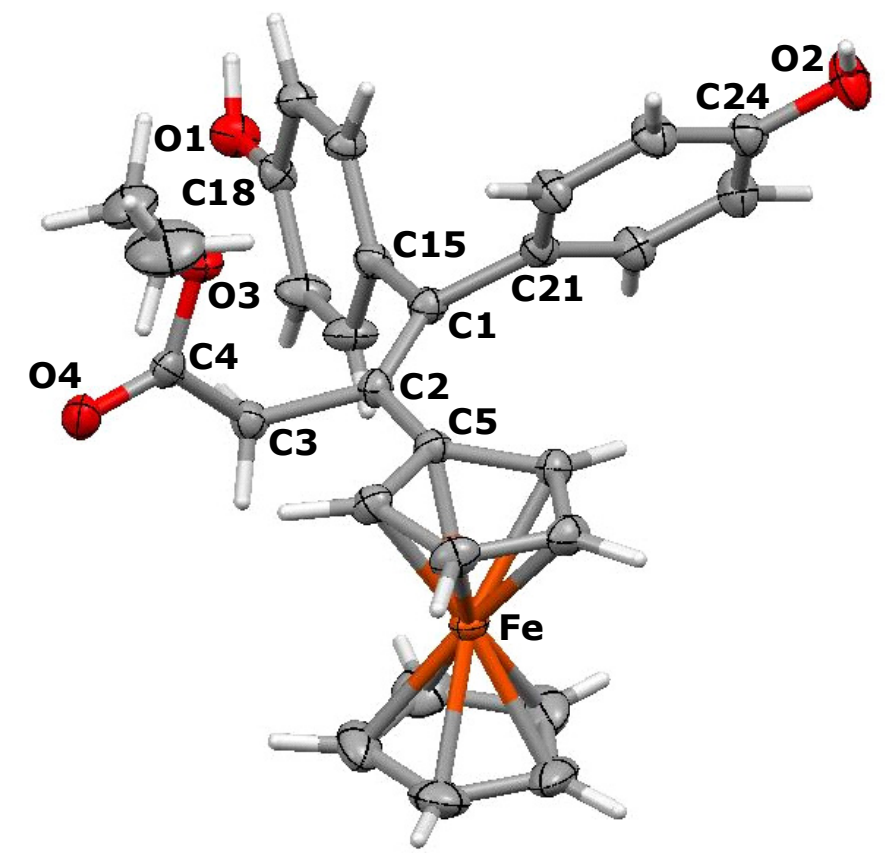

The $\mathrm{C}_{5} \mathrm{H}_{4}$ ring of the ferrocenyl substituent is twisted through $27^{\circ}$ out of the plane of the double bond, whereas the $Z$ and $E$ phenolic rings are rotated through $60.4^{\circ}$ and $64.3^{\circ}$, respectively, in opposite directions, making a dihedral angle between them of $89.3^{\circ}$. The cyclopentadienyl rings in the ferrocenyl moiety are parallel and are separated by $3.329 \AA$. The results of all the coupling reactions are summarized in Table 1 . 
Table 1. Collected results from the McMurry coupling reactions.

\begin{tabular}{|c|c|c|c|c|}
\hline Entry & Ketone 1 & Ketone 2 & $\begin{array}{l}\text { Product } \\
\text { (Yield) }\end{array}$ & Comments \\
\hline 1 & $\mathrm{FcC}(=\mathrm{O}) \mathrm{CH}_{2} \mathrm{Cl}$ & $p-\mathrm{HO}-\mathrm{C}_{6} \mathrm{H}_{4}-\mathrm{C}(=\mathrm{O}) \mathrm{Et}$ & $9(29 \%)$ & Rearrangement with exchange of $\mathrm{Cl} \rightarrow \mathrm{H}$ \\
\hline 2 & $\mathrm{FcC}(=\mathrm{O}) \mathrm{CH}_{2} \mathrm{Cl}$ & $\left(p-\mathrm{HO}-\mathrm{C}_{6} \mathrm{H}_{4}\right)_{2} \mathrm{C}=\mathrm{O}$ & $10(49 \%)$ & Alkene with exchange $\mathrm{Cl} \rightarrow \mathrm{H}$ \\
\hline 3 & $\mathrm{FcC}(=\mathrm{O}) \mathrm{Me}$ & $\left(p-\mathrm{HO}-\mathrm{C}_{6} \mathrm{H}_{4}\right)_{2} \mathrm{C}=\mathrm{O}$ & $10(90 \%)$ & Alkene \\
\hline 4 & $\mathrm{FcC}(=\mathrm{O})\left(\mathrm{CH}_{2}\right)_{2} \mathrm{Cl}$ & $p-\mathrm{HO}-\mathrm{C}_{6} \mathrm{H}_{4}-\mathrm{C}(=\mathrm{O}) \mathrm{Me}$ & $\mathbf{5 a}(10 \%)$ & Alkene with exchange $\mathrm{Cl} \rightarrow \mathrm{OH}$ \\
\hline 5 & $\mathrm{FcC}(=\mathrm{O})\left(\mathrm{CH}_{2}\right)_{2} \mathrm{Cl}$ & $p-\mathrm{HO}-\mathrm{C}_{6} \mathrm{H}_{4}-\mathrm{C}(=\mathrm{O}) \mathrm{Et}$ & $\mathbf{5 b}(16 \%)$ & Alkene with exchange $\mathrm{Cl} \rightarrow \mathrm{OH}$ \\
\hline 6 & $\mathrm{FcC}(=\mathrm{O})\left(\mathrm{CH}_{2}\right)_{2} \mathrm{Cl}$ & $p-\mathrm{HO}-\mathrm{C}_{6} \mathrm{H}_{4}-\mathrm{C}(=\mathrm{O}) \mathrm{Pr}$ & $\mathbf{5 c}(15 \%)$ & Alkene with exchange $\mathrm{Cl} \rightarrow \mathrm{OH}$ \\
\hline 7 & $\mathrm{FcC}(=\mathrm{O})\left(\mathrm{CH}_{2}\right)_{2} \mathrm{Cl}$ & $p-\mathrm{HO}-\mathrm{C}_{6} \mathrm{H}_{4}-\mathrm{C}(=\mathrm{O}) \mathrm{H}$ & ----- & Complex inseparable mixture \\
\hline 8 & $\mathrm{FcC}(=\mathrm{O})\left(\mathrm{CH}_{2}\right)_{2} \mathrm{Cl}$ & $\left(p-\mathrm{HO}-\mathrm{C}_{6} \mathrm{H}_{4}\right)_{2} \mathrm{C}=\mathrm{O}$ & $2(47 \%)$ & $\begin{array}{l}\text { Alkene, no exchange, } \\
\text { published work [26] }\end{array}$ \\
\hline 9 & $\mathrm{FcC}(=\mathrm{O}) \mathrm{Et}$ & $p-\mathrm{HO}-\mathrm{C}_{6} \mathrm{H}_{4}-\mathrm{C}(=\mathrm{O}) \mathrm{Et}$ & $4(30 \%)$ & $\begin{array}{l}\text { Alkene, and also isolation of a } \\
\text { rearrangement product, } 14\end{array}$ \\
\hline 10 & $\mathrm{FcC}(=\mathrm{O}) \mathrm{Et}$ & $p-\mathrm{MeO}-\mathrm{C}_{6} \mathrm{H}_{4}-\mathrm{C}(=\mathrm{O}) \mathrm{Et}$ & $13(33 \%)$ & Alkene \\
\hline 11 & $\mathrm{FcC}(=\mathrm{O}) \mathrm{CH}_{2} \mathrm{CO}_{2} \mathrm{Et}$ & $p$-HO- $\mathrm{C}_{6} \mathrm{H}_{4}-\mathrm{C}(=\mathrm{O}) \mathrm{Et}$ & ----- & Homocoupling (DES) \\
\hline 12 & $\mathrm{FcC}(=\mathrm{O}) \mathrm{CH}_{2} \mathrm{CO}_{2} \mathrm{Et}$ & $\left(p-\mathrm{HO}-\mathrm{C}_{6} \mathrm{H}_{4}\right)_{2} \mathrm{C}=\mathrm{O}$ & $\begin{array}{c}\mathbf{1 7 b} \\
(11 \%)\end{array}$ & Alkene \\
\hline 13 & $\mathrm{FcC}(=\mathrm{O}) \mathrm{CH}_{2} \mathrm{CO}_{2} \mathrm{Et}$ & $\left(p-\mathrm{HO}-\mathrm{C}_{6} \mathrm{H}_{4}\right)_{2} \mathrm{C}=\mathrm{O}$ & $\begin{array}{c}17 \mathbf{b} \\
(40 \%)\end{array}$ & $\begin{array}{l}\text { Alkene when using } 2 \text { eq of } \\
\left(p-\mathrm{HOC}_{6} \mathrm{H}_{4}\right)_{2} \mathrm{C}=\mathrm{O}\end{array}$ \\
\hline
\end{tabular}

\subsection{Mechanistic Considerations}

The failure of McMurry reactions of chloroalkyl-ferrocenyl ketones to yield chlorinated products raises interesting questions. In the case of chloroacetylferrocene, the chlorine was replaced by hydrogen (entries 1 and 2 of Table 1), whereas reactions of chloropropionylferrocene with mono-aryl ketones led to hydroxyethyl derivatives 5a-c (entries 4-6).

We consider first the case of chloroacetylferrocene, 8, originally prepared by Schlögl and Egger [31] by Friedel-Crafts acylation of ferrocene in the presence of $\mathrm{AlCl}_{3}$. In particular, we note their report that, when a solution of 8 in $\mathrm{CS}_{2}$ or $\mathrm{CH}_{2} \mathrm{Cl}_{2}$ was stirred with $\mathrm{AlCl}_{3}$ for two hours at room temperature, it suffered dechlorination to form acetylferrocene, 11, whose identity was confirmed by independent synthesis. Apparently, abstraction of chloride by the Lewis acid to form $\mathrm{AlCl}_{4}{ }^{-}$leads initially to formation of the corresponding primary carbocation that is presumably stabilized as the strained three-membered cyclic ferrocenyl-stabilized cation $\mathbf{1 8}$ (Scheme 6). Reduction to form the methyl group in $\mathbf{1 1}$ requires formal addition of a hydride, and such a process is well-known to proceed under Friedel-Crafts conditions whereby abstraction of hydride can occur-even from an alkane! [33]. Now, assuming that a Lewis acidic titanium chloride can behave analogously by abstracting a chloride from $\mathbf{8}$, there is a straightforward explanation for the conversion of a chloroacetyl substituent into the corresponding acetyl derivative, as in $\mathbf{1 0}$ (entry 2).

Turning now to the generation of the hydroxyethyl substituents in $\mathbf{5 a}-\mathbf{c}$, once again one can envisage abstraction of chloride to form a primary cation that cyclises to the somewhat less strained four-membered ferrocenyl-stabilized cation 19 (Scheme 7). Attachment of $\mathrm{TiCl}_{2}$ to the two ketonic oxygens, addition of hydride and elimination of $\mathrm{TiOCl}_{2}$ can lead to the observed products. However, the hydride abstraction process is rather inefficient and the observed yields are low. It is now apparent 
why hydroxyethylation is observed in reactions of chloropropionylferrocene, 6 , with mono-aryl ketones when there is a possible source of hydride by abstraction from the alkyl group, but is not possible in reactions involving a diaryl ketone. This also provides a rationale for the non-formation of a hydroxyethyl derivative from 4-hydroxybenzaldehyde (entry 7 in Table 1).

Scheme 6. Proposed mechanism for the Lewis acid promoted conversion of a chloromethyl substituent into a methyl group.

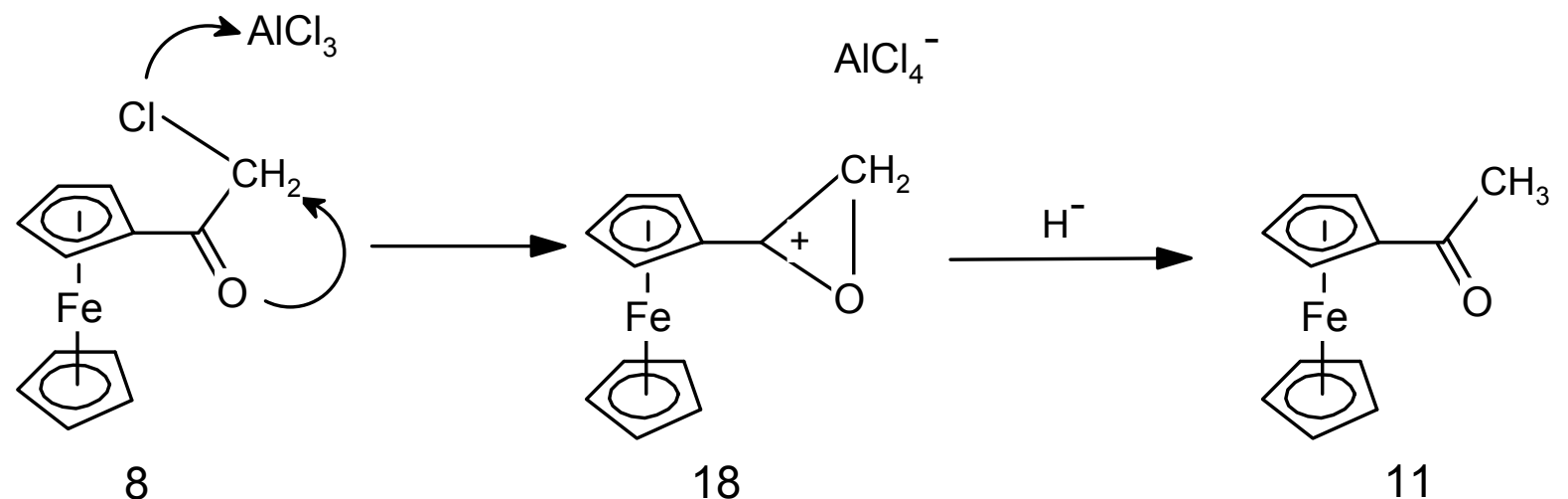

Scheme 7. Proposed mechanism for the Lewis acid promoted conversion of a chloroethyl substituent into a hydroxyethyl group.

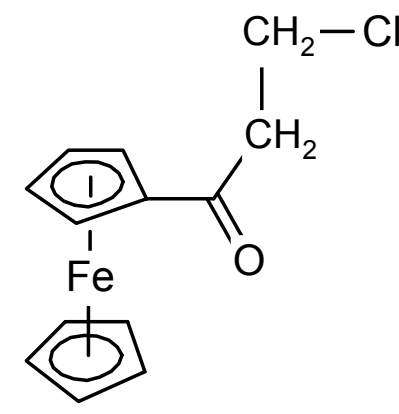

6

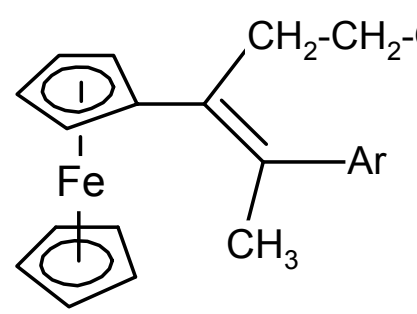

$5 a$
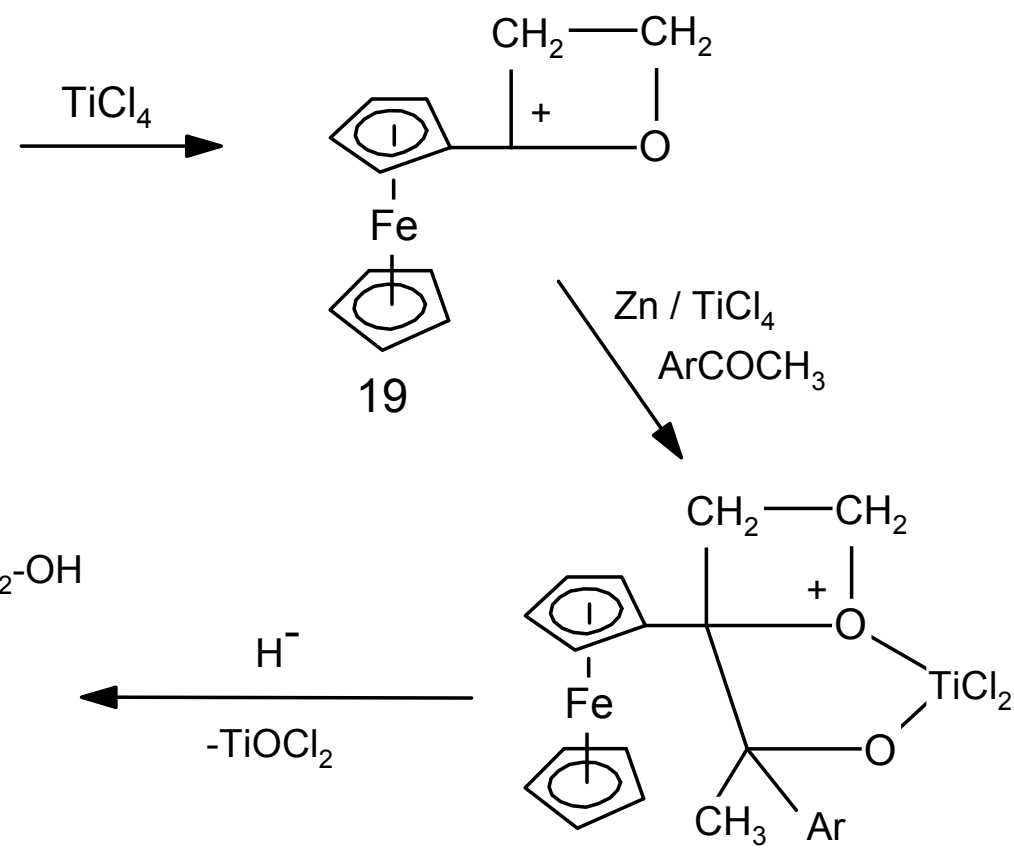

\subsection{Biological Results}

The $\mathrm{IC}_{50}$ values $(\mu \mathrm{M})$ of most of the new isolated compounds were measured on hormone-independent breast cancer cells MDA-MB-231, and are collected in Table 2. The $\mathrm{IC}_{50}$ values of ferrocidiphenol 1 and ferrociphenol are also included for the sake of comparison $[10,34]$. 
Table 2. $\mathrm{IC}_{50}$ values $(\mu \mathrm{M})$. a: value from reference [10], b: value from reference [26], c: value from reference [34], d: value from reference [35]

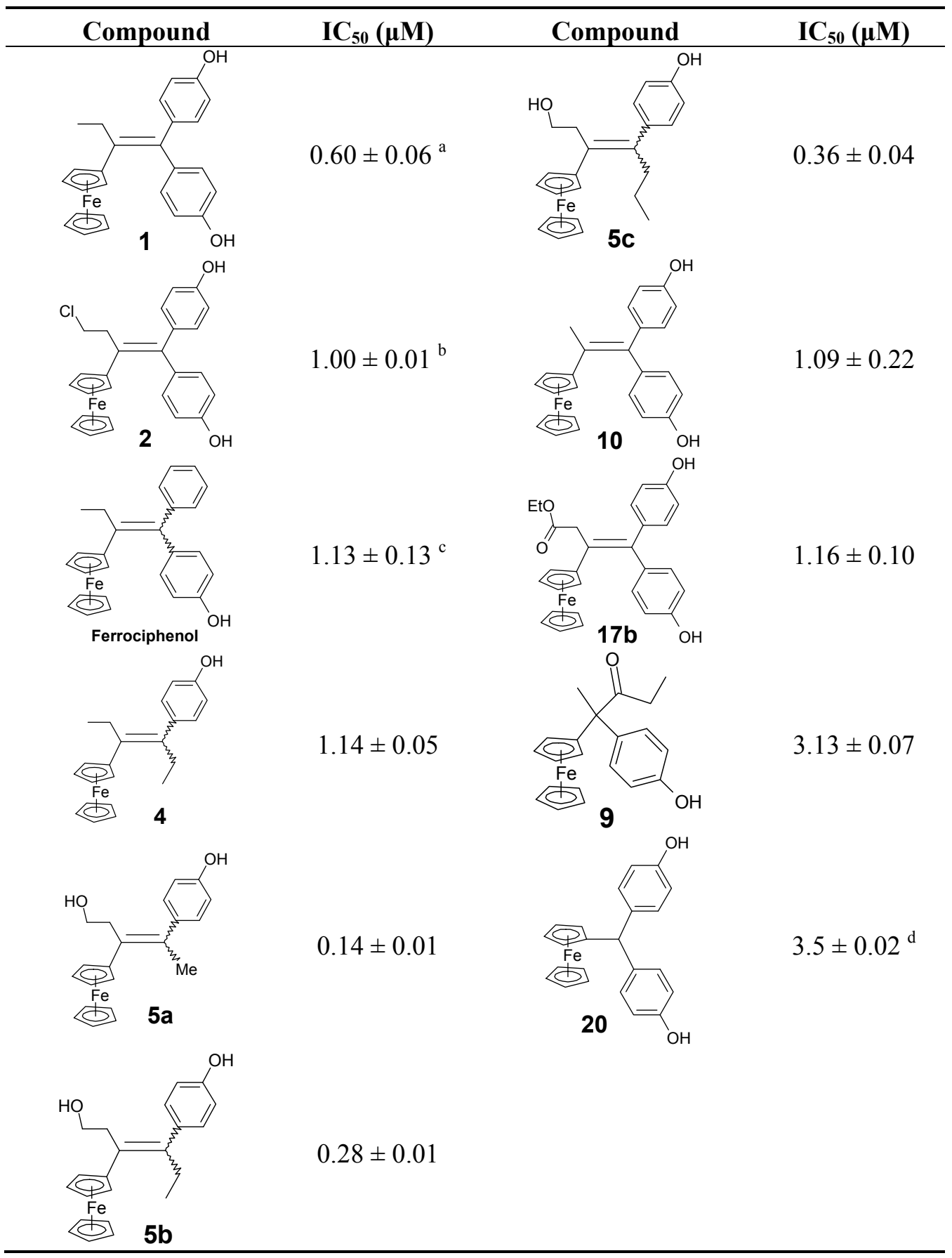

It is noteworthy that compounds $\mathbf{5 a - c}$, which contain the hydroxyethyl group, are more active than the related ferrocidiphenol, $\mathbf{1}$, with $\mathrm{IC}_{50}$ values for $\mathbf{5 a}, \mathbf{5 b}$ and $\mathbf{5 c}$ of $0.14,0.28$ and $0.36 \mu \mathrm{M}$, respectively. Indeed, compound $5 \mathbf{a}\left(\mathrm{IC}_{50}=0.14 \mu \mathrm{M}\right)$ is four times more potent than $\mathbf{1}\left(\mathrm{IC}_{50}=0.60 \mu \mathrm{M}[10]\right)$. We have shown previously that compounds of the ferrociphenol type have a higher activity when they possess two para phenol groups (or two biologically hydrolysable ester groups [36]) as compared to compounds bearing only one phenol group [34,37,38]. Hence, as listed in Table 2, the ferrocidiphenol, $\mathbf{1}$, with two phenol groups, is more active than its monophenol analogue, $\mathrm{Fc}(\mathrm{Et}) \mathrm{C}=\mathrm{CPh}\left(\mathrm{C}_{6} \mathrm{H}_{4} \mathrm{OH}\right)$, which shows an $\mathrm{IC}_{50}$ value of $1.13 \mu \mathrm{M}$ [34]. It appears, therefore, that the hydroxyethyl group imparts a stronger 
antiproliferative effect than a phenol group. Moreover, it appears that the length of the alkyl chain in the series 5a-c (methyl, ethyl and propyl) plays a significant role; even though the differences are not very large, it seems that the smaller the substituent the more active is the compound. The important role of the hydroxyethyl group is confirmed by the lower activity of compound 4 which lacks the hydroxyl function, whereby its $\mathrm{IC}_{50}$ value $(1.14 \mu \mathrm{M})$ is four times less active than $\mathbf{5 b}\left(\mathrm{IC}_{50}=0.28 \mu \mathrm{M}\right)$, and at the same level than the ferrociphenol with a single phenolic substituent. We note that replacement of the ethyl group of the ferrocidiphenol, $\mathbf{1}$, by a methyl group in compound $\mathbf{1 0}$ led to a decrease in activity. One might have anticipated that the smaller alkyl substituent would have led to somewhat enhanced activity, but the subtle change in electronic effects may have somewhat disfavored formation of the expected quinone methide metabolite [19].

Finally, we note that the pinacolone 9 is not very active, with an $\mathrm{IC}_{50}$ value of only $3.13 \mu \mathrm{M}$. This again supports the idea that the [ferrocenyl-double bond-phenol] motif is crucial for antiproliferative activity in this series of compounds. Compound $\mathbf{9}$ has approximately the same $\mathrm{IC}_{50}$ as ferrocenyl-di(4hydroxyphenyl)methane, 20, $(3.5 \mu \mathrm{M})$ [35], which also possesses a saturated central carbon impairing electronic circulation.

\section{Experimental Section}

\subsection{General Information}

All reactions and manipulations were carried out under an argon atmosphere using standard Schlenk techniques. THF was distilled over sodium/benzophenone prior to use. Thin layer chromatography was performed on silica gel $60 \mathrm{GF}_{254}$. The semi-preparative HPLC separations were performed on a Shimadzu instrument with a Nucleodur C18 column (length of $25 \mathrm{~cm}$, diameter of $3.2 \mathrm{~cm}$, and particle size of $10 \mu \mathrm{m}$ ) using acetonitrile/water as eluent. IR spectra were obtained on a FT/IR-4100 JASCO 180 spectrometer. ${ }^{1} \mathrm{H}$ and ${ }^{13} \mathrm{C}$-NMR spectra were acquired on a Bruker $300 \mathrm{MHz}$ spectrometer, while 2D NMR spectra were obtained on a Bruker $400 \mathrm{MHz}$ instrument. Mass spectrometry was carried out at the "Service de Spectrométrie de Masse" at ENSCP, Paris. High resolution mass spectra (HRMS) and RX structures were acquired in the "Institut Parisien de Chimie Moléculaire (IPCM-UMR 8232)" at the "Université Pierre et Marie Curie", Paris. Microanalyses were performed by the "Service de Microanalyse ICSN" at Gif sur Yvette, France. Determination of the cytotoxicity of the complexes was performed at IMAGIF (ICSN, Gif sur Yvette, France).

\subsection{Chemistry}

General Procedure for McMurry Coupling Reactions

Zinc powder was suspended in dry THF at room temperature in a Schlenk tube under argon, and titanium tetrachloride was added slowly via a syringe while stirring. The reaction mixture was heated at reflux for $2 \mathrm{~h}$, after which time a THF solution containing the two ketones was added, and the mixture was heated at reflux for a further two hours. The reaction mixture was cooled, poured into water, acidified with $\mathrm{HCl}$ until the dark color disappeared and extracted with dichloromethane. The organic layer was washed with water, dried over magnesium sulfate, filtered and concentrated under 
reduced pressure. The crude mixture was chromatographed on silica gel column using a mixture of dichloromethane/acetone 90/10 as an eluent and/or purified by semi-preparative HPLC using a mixture of acetonitrile/water as an eluent.

3-Ferrocenyl-4-(4-hydroxyphenyl)-hex-3-ene (4) (and rearrangement product 14). Zinc powder (1.82 g, $27.9 \mathrm{mmol})$, titanium tetrachloride $(2.04 \mathrm{~mL}, 18.6 \mathrm{mmol})$, propionylferrocene $(1.13 \mathrm{~g}, 4.65 \mathrm{mmol})$, p-hydroxypropiophenone $(0.70 \mathrm{~g}, 4.65 \mathrm{mmol})$. After column chromatography followed by preparative HPLC (acetonitrile/water 90/10), and recrystallization from a pentane/diethylether, 4 was obtained as orange crystals $\left(0.50 \mathrm{~g}, 30 \%\right.$ yield) consisting of a mixture of $Z$ and $E$ isomers (63/37). ${ }^{1} \mathrm{H}-\mathrm{NMR}$ (300 MHz, $\left.\mathrm{CDCl}_{3}\right): \delta 0.92\left(\mathrm{t}, J=7.5 \mathrm{~Hz}, 3 \mathrm{H}, \mathrm{CH}_{3}\right), 1.24\left(\mathrm{t}, J=7.5 \mathrm{~Hz}, 3 \mathrm{H}, \mathrm{CH}_{3}\right), 2.28$ and 2.41 (q, $\left.J=7.5 \mathrm{~Hz}, 2 \mathrm{H}, \mathrm{CH}_{2}\right), 2.53$ and 2.61 (q, $\left.J=7.5 \mathrm{~Hz}, 2 \mathrm{H}, \mathrm{CH}_{2}\right), 3.70$ and $4.24\left(\mathrm{~s}, 2 \mathrm{H}, \mathrm{C}_{5} \mathrm{H}_{4}\right), 3.97$ and $4.35\left(\mathrm{~s}, 2 \mathrm{H}, \mathrm{C}_{5} \mathrm{H}_{4}\right), 4.03$ and $4.15(\mathrm{~s}, 5 \mathrm{H}, \mathrm{Cp}), 4.70$ and $4.72(\mathrm{~s}, 1 \mathrm{H}, \mathrm{OH}), 6.77$ and $6.82(\mathrm{~d}, J=8.5 \mathrm{~Hz}$, $\left.2 \mathrm{H}, \mathrm{C}_{6} \mathrm{H}_{4}\right), 6.90$ and $7.00\left(\mathrm{~d}, J=8.5 \mathrm{~Hz}, 2 \mathrm{H}, \mathrm{C}_{6} \mathrm{H}_{4}\right) \cdot{ }^{13} \mathrm{C}-\mathrm{NMR}\left(75.4 \mathrm{MHz}, \mathrm{CDCl}_{3}\right): \delta 13.0$ and 13.2 $\left(\mathrm{CH}_{3}\right), 15.3$ and $16.0\left(\mathrm{CH}_{3}\right), 26.7$ and $28.4\left(\mathrm{CH}_{2}\right), 28.8$ and $29.5\left(\mathrm{CH}_{2}\right), 67.8$ and $67.9\left(2 \mathrm{CH}, \mathrm{C}_{5} \mathrm{H}_{4}\right)$, 69.0 and $69.1\left(2 \mathrm{CH}, \mathrm{C}_{5} \mathrm{H}_{4}\right), 69.1$ and $69.2(5 \mathrm{CH}, \mathrm{Cp}), 77.4\left(\mathrm{C}, \mathrm{C}_{5} \mathrm{H}_{4}\right), 115.1$ and $115.2\left(2 \mathrm{CH}_{2} \mathrm{C}_{6} \mathrm{H}_{4}\right)$, 130.1 and $130.5\left(2 \mathrm{CH}, \mathrm{C}_{6} \mathrm{H}_{4}\right), 133.3(\mathrm{C}), 137.1$ and $137.2(\mathrm{C}), 138.0(\mathrm{C}), 153.8$ and $153.9(\mathrm{C})$. IR $\left(\mathrm{KBr}, v \mathrm{~cm}^{-1}\right): 3418(\mathrm{OH}), 3094,3062,2929,2871\left(\mathrm{CH}_{2}, \mathrm{CH}_{3}\right)$. MS (EI, $\left.70 \mathrm{eV}\right) \mathrm{m} / z: 360$ [M] $]^{+}, 331$ $[\mathrm{M}-\mathrm{Et}]^{+}, 295[\mathrm{M}-\mathrm{Cp}]^{+}, 121[\mathrm{CpFe}]^{+}$. MS $\left(\mathrm{CI}, \mathrm{CH}_{4}\right) \mathrm{m} / z: 361[\mathrm{M}+\mathrm{H}]^{+}, 360[\mathrm{M}]^{+}, 295$. HRMS (ESI, $\mathrm{C}_{22} \mathrm{H}_{24} \mathrm{FeO}:[\mathrm{M}]^{+}$) calcd: 360.11765 , found: 360.11711 .

3-Ferrocenyl-3-(4-hydroxyphenyl)-hexan-4-one (14). A sample of the transposition product 14 was isolated from the chromatography of the crude mixture of the reaction of McMurry giving 4. HPLC (acetonitrile/water 80/20) then recrystallization from a pentane/diethylether mixture, 14 was obtained as orange crystals. ${ }^{1} \mathrm{H}-\mathrm{NMR}\left(300 \mathrm{MHz}, \mathrm{CDCl}_{3}\right): \delta 0.73\left(\mathrm{t}, J=7.4 \mathrm{~Hz}, 3 \mathrm{H}, \mathrm{CH}_{3}\right), 0.97(\mathrm{t}, J=7.2 \mathrm{~Hz}$, $\left.3 \mathrm{H}, \mathrm{CH}_{3}\right), 1.95-2.40\left(\mathrm{~m}, 4 \mathrm{H}, \mathrm{CH}_{2}\right), 3.96\left(\mathrm{~s}, 1 \mathrm{H}, \mathrm{C}_{5} \mathrm{H}_{4}\right), 4.09\left(\mathrm{~s}, 1 \mathrm{H}, \mathrm{C}_{5} \mathrm{H}_{4}\right), 4.14(\mathrm{~s}, 5 \mathrm{H}, \mathrm{Cp}), 4.22$ (s, $\left.1 \mathrm{H}, \mathrm{C}_{5} \mathrm{H}_{4}\right), 4.25\left(\mathrm{~s}, 1 \mathrm{H}, \mathrm{C}_{5} \mathrm{H}_{4}\right), 4.85(\mathrm{~s}, 1 \mathrm{H}, \mathrm{OH}), 6.79\left(\mathrm{~d}, J=6.6 \mathrm{~Hz}, 2 \mathrm{H}, \mathrm{C}_{6} \mathrm{H}_{4}\right), 7.14(\mathrm{~d}, J=6.6 \mathrm{~Hz}$, $\left.2 \mathrm{H}, \mathrm{C}_{6} \mathrm{H}_{4}\right) .{ }^{13} \mathrm{C}-\mathrm{NMR}\left(75.5 \mathrm{MHz}, \mathrm{CDCl}_{3}\right): \delta 9.0\left(\mathrm{CH}_{3}\right), 10.3\left(\mathrm{CH}_{3}\right), 31.1\left(\mathrm{CH}_{2}\right), 32.9\left(\mathrm{CH}_{2}\right), 59.8(\mathrm{C})$, $67.4\left(\mathrm{CH}, \mathrm{C}_{5} \mathrm{H}_{4}\right), 67.9\left(\mathrm{CH}, \mathrm{C}_{5} \mathrm{H}_{4}\right), 68.0\left(\mathrm{CH}, \mathrm{C}_{5} \mathrm{H}_{4}\right), 69.0\left(\mathrm{CH}, \mathrm{C}_{5} \mathrm{H}_{4}\right), 69.3(5 \mathrm{CH}, \mathrm{Cp}), 91.3\left(\mathrm{C}, \mathrm{C}_{5} \mathrm{H}_{4}\right)$, $114.7\left(2 \mathrm{CH}, \mathrm{C}_{6} \mathrm{H}_{4}\right), 129.6\left(2 \mathrm{CH}+\mathrm{C}, \mathrm{C}_{6} \mathrm{H}_{4}\right), 154.1\left(\mathrm{C}, \mathrm{C}_{6} \mathrm{H}_{4}\right), 211.4(\mathrm{CO}) . \mathrm{IR}\left(\mathrm{KBr}, v \mathrm{~cm}^{-1}\right): 3454$ (OH), 2991, 2971, 2935, $2878\left(\mathrm{CH}_{2}, \mathrm{CH}_{3}\right), 1684$ (CO). MS (ESI+, $\left.\mathrm{NH}_{3}, \mathrm{C}_{22} \mathrm{H}_{24} \mathrm{FeO}_{2}\right) \mathrm{m} / z: 376$ [M] ${ }^{+}$, $394\left[\mathrm{M}+\mathrm{NH}_{4}\right]^{+}, 399[\mathrm{M}+\mathrm{Na}]^{+}$. MS (ESI-, $\left.\mathrm{C}_{22} \mathrm{H}_{24} \mathrm{FeO}_{2}\right) \mathrm{m} / z: 375[\mathrm{M}-\mathrm{H}]^{-}, 751[2 \mathrm{M}-\mathrm{H}]^{-}$. Anal. Calcd for $\mathrm{C}_{22} \mathrm{H}_{24} \mathrm{FeO}_{2} .\left(\mathrm{H}_{2} \mathrm{O}\right)_{0.1}$ : C, 69.89; H, 6.45. Found: C, 69.61; H, 6.36.

3-Ferrocenyl-4-(4-hydroxyphenyl)-1-hydroxy-pent-3-ene (5a). Zinc powder (2.35 g, $36 \mathrm{mmol})$, titanium tetrachloride $(2.64 \mathrm{~mL}, 24 \mathrm{mmol})$, ferrocenyl 2-chloroethyl ketone (1.66 g, $6 \mathrm{mmol}$ ), $p$-hydroxyacetophenone $(0.82 \mathrm{~g}, 6 \mathrm{mmol})$. HPLC (acetonitrile/water $80 / 20$ ) then recrystallization from a pentane/diethylether mixture, 5a was obtained as bright yellow crystals $(0.21 \mathrm{~g}, 10 \%$ yield) consisting of a mixture of $Z$ and $E$ isomers $(73 / 27)$. ${ }^{1} \mathrm{H}-\mathrm{NMR}\left(300 \mathrm{MHz}\right.$, acetone- $\left.d_{6}\right): \delta 2.11(\mathrm{~s}, 3 \mathrm{H}$, $\left.\mathrm{CH}_{3}\right), 2.68$ and $2.97\left(\mathrm{t}, J=8.7 \mathrm{~Hz}, 2 \mathrm{H}, \mathrm{CH}_{2}\right), 3.41-3.55$ and $3.74-3.83\left(\mathrm{~m}, 2 \mathrm{H}, \mathrm{CH}_{2} \mathrm{O}\right), 3.81$ and 4.28 (t, $\left.J=1.8 \mathrm{~Hz}, 2 \mathrm{H}, \mathrm{C}_{5} \mathrm{H}_{4}\right), 3.98$ and $4.43\left(\mathrm{t}, J=1.8 \mathrm{~Hz}, 2 \mathrm{H}, \mathrm{C}_{5} \mathrm{H}_{4}\right), 4.07$ and $4.20(\mathrm{~s}, 5 \mathrm{H}, \mathrm{Cp}), 6.75$ and $6.85\left(\mathrm{~d}, J=8.7 \mathrm{~Hz}, 2 \mathrm{H}, \mathrm{C}_{6} \mathrm{H}_{4}\right), 6.88$ and $7.06\left(\mathrm{~d}, J=8.7 \mathrm{~Hz}, 2 \mathrm{H}, \mathrm{C}_{6} \mathrm{H}_{4}\right), 8.19$ and $8.24(\mathrm{~s}, 1 \mathrm{H}, \mathrm{OH})$. ${ }^{13} \mathrm{C}-\mathrm{NMR}\left(75.4 \mathrm{MHz}\right.$, acetone- $\left.d_{6}\right): \delta 23.0\left(\mathrm{CH}_{3}\right), 38.9\left(\mathrm{CH}_{2}\right), 62.6\left(\mathrm{CH}_{2} \mathrm{O}\right), 68.1\left(2 \mathrm{CH}, \mathrm{C}_{5} \mathrm{H}_{4}\right), 69.5$ 
(5CH, Cp), $69.7\left(2 \mathrm{CH}, \mathrm{C}_{5} \mathrm{H}_{4}\right), 86.7\left(\mathrm{C}, \mathrm{C}_{5} \mathrm{H}_{4}\right), 115.9\left(2 \mathrm{CH}, \mathrm{C}_{6} \mathrm{H}_{4}\right), 130.4\left(2 \mathrm{CH}, \mathrm{C}_{6} \mathrm{H}_{4}\right), 145.1(\mathrm{C})$, $156.4(\mathrm{C}), 157.0(\mathrm{C}), 161.0(\mathrm{C})$. IR (KBr, $\left.v \mathrm{~cm}^{-1}\right)$ : $3444(\mathrm{OH}), 2959,2933,2882\left(\mathrm{CH}_{2}, \mathrm{CH}_{3}\right)$. HRMS $\left(\mathrm{CI}, \mathrm{CH}_{4}, \mathrm{C}_{21} \mathrm{H}_{23} \mathrm{FeO}_{2}\right.$ : $[\mathrm{M}+\mathrm{H}]^{+}$) calcd: 363.1048 , found: 363.1047. Anal. Calcd for $\mathrm{C}_{21} \mathrm{H}_{22} \mathrm{FeO}_{2} \cdot \mathrm{H}_{2} \mathrm{O}$ : C, 66.32; H, 6.36. Found: C, 66.63; H, 6.35.

3-Ferrocenyl-4-(4-hydroxyphenyl)-1-hydroxy-hex-3-ene (5b). Zinc powder (0.79 g, $12 \mathrm{mmol})$, titanium tetrachloride $(1.51 \mathrm{~mL}, 8 \mathrm{mmol})$, ferrocenyl 2-chloroethyl ketone $(0.55 \mathrm{~g}, 2 \mathrm{mmol})$, p-hydroxypropiophenone $(0.30 \mathrm{~g}, 2 \mathrm{mmol})$. HPLC (acetonitrile/water $80 / 20)$ then recrystallization from a pentane/diethylether mixture, $5 \mathbf{b}$ was obtained as bright yellow crystals $(0.12 \mathrm{~g}, 16 \%$ yield) consisting of a mixture of $Z$ and $E$ isomers (86/14). ${ }^{1} \mathrm{H}-\mathrm{NMR}\left(300 \mathrm{MHz}\right.$, acetone- $\left.d_{6}\right)$ : $\delta 0.93$ and 0.94 (t, $J=7.4 \mathrm{~Hz}, 2 \mathrm{H}, \mathrm{CH}_{3}$ ), 2.50 and 2.55 (q, $J=7.4 \mathrm{~Hz}, \mathrm{CH}_{2}$ ), 2.68 and 2.97 (t, $J=7.9 \mathrm{~Hz}, 2 \mathrm{H}, \mathrm{CH}_{2}$ ), 3.39-3.58 and 3.77-3.86 (m, 2H, $\left.\mathrm{CH}_{2} \mathrm{OH}\right), 3.80$ and 4.30 (t, $\left.J=1.9 \mathrm{~Hz}, 2 \mathrm{H}, \mathrm{C}_{5} \mathrm{H}_{4}\right), 4.00$ and 4.43 (t, $\left.J=1.9 \mathrm{~Hz}, 2 \mathrm{H}, \mathrm{C}_{5} \mathrm{H}_{4}\right), 4.08$ and $4.23(\mathrm{~s}, 5 \mathrm{H}, \mathrm{Cp}), 6.82$ and $6.88\left(\mathrm{~d}, J=8.6 \mathrm{~Hz}, 2 \mathrm{H}, \mathrm{C}_{6} \mathrm{H}_{4}\right), 6.90$ and $7.04\left(\mathrm{~d}, J=8.6 \mathrm{~Hz}, 2 \mathrm{H}, \mathrm{C}_{6} \mathrm{H}_{4}\right), 8.23$ and $8.26(\mathrm{~s}, 1 \mathrm{H}, \mathrm{OH}) .{ }^{13} \mathrm{C}-\mathrm{NMR}\left(75.4 \mathrm{MHz}\right.$, acetone- $\left.\mathrm{d}_{6}\right): \delta 13.9$ and $14.2\left(\mathrm{CH}_{3}\right), 29.8$ and $30.6\left(\mathrm{CH}_{2}\right), 40.8\left(\mathrm{CH}_{2}\right), 63.4$ and $64.2\left(\mathrm{CH}_{2} \mathrm{O}\right), 69.0$ and $69.3\left(2 \mathrm{CH}, \mathrm{C}_{5} \mathrm{H}_{4}\right)$, 70.4 and $70.6(5 \mathrm{CH}, \mathrm{Cp}), 70.5$ and $70.6\left(2 \mathrm{CH}, \mathrm{C}_{5} \mathrm{H}_{4}\right), 90.1$ and $91.1\left(\mathrm{C}, \mathrm{C}_{5} \mathrm{H}_{4}\right), 116.5$ and $116.7(2 \mathrm{CH}$, $\left.\mathrm{C}_{6} \mathrm{H}_{4}\right), 131.3$ and $131.7\left(2 \mathrm{CH}, \mathrm{C}_{6} \mathrm{H}_{4}\right), 136.3$ and $136.7(\mathrm{C}), 141.7(\mathrm{C}), 143.6(\mathrm{C}), 157.4$ and $157.5(\mathrm{C})$. MS (EI, $70 \mathrm{eV}$ ) m/z: $376[\mathrm{M}]^{+}$. Anal. Calcd. for $\mathrm{C}_{22} \mathrm{H}_{24} \mathrm{O}_{2} \mathrm{Fe}: \mathrm{C}, 70.23 ; \mathrm{H}, 6.43$. Found: C, 70.48; $\mathrm{H}$, 6.69. A second recrystallization gave pure major isomer which was identified as the $Z$ isomer by 2D NMR experiments.

3-Ferrocenyl-4-(4-hydroxyphenyl)-1-hydroxy-hept-3-ene (5c). Zinc powder (3.14 g, $48 \mathrm{mmol})$, titanium tetrachloride $(3.52 \mathrm{~mL}, 32 \mathrm{mmol})$, ferrocenyl 2-chloroethyl ketone $(2.21 \mathrm{~g}, 8 \mathrm{mmol})$, p-hydroxybutyrophenone $(1.31 \mathrm{~g}, 8 \mathrm{mmol})$. HPLC (acetonitrile/water $80 / 20)$ then recrystallization from a pentane/diethylether mixture, $5 \mathbf{c}$ was obtained as bright yellow crystals $(0.45 \mathrm{~g}, 15 \%$ yield $)$ consisting of a mixture of $Z$ and $E$ isomers (62/38). ${ }^{1} \mathrm{H}-\mathrm{NMR}\left(300 \mathrm{MHz}\right.$, acetone- $\left.\mathrm{d}_{6}\right): \delta 0.89$ (t, $J=7.4 \mathrm{~Hz}, 3 \mathrm{H}, \mathrm{CH}_{3}$ ), 1.29-1.33 (m, 2H, $\left.\mathrm{CH}_{2}\right), 2.40$ and 2.45 (t, $\left.J=7.4,2 \mathrm{H}, \mathrm{CH}_{2}\right), 2.65$ and 2.93 (t, $J=7.4,2 \mathrm{H}, \mathrm{CH}_{2}$ ), 3.36-3.53 and 3.75-3.82 (m, 2H, $\left.\mathrm{CH}_{2} \mathrm{O}\right), 3.76$ and $4.26\left(\mathrm{t}, J=1.8 \mathrm{~Hz}, 2 \mathrm{H}, \mathrm{C}_{5} \mathrm{H}_{4}\right), 3.96$ and 4.36 (t, $\left.J=1.8 \mathrm{~Hz}, 2 \mathrm{H}, \mathrm{C}_{5} \mathrm{H}_{4}\right), 4.04$ and $4.19(\mathrm{~s}, 5 \mathrm{H}, \mathrm{Cp}), 6.78$ and $6.84\left(\mathrm{~d}, J=8.7 \mathrm{~Hz}, 2 \mathrm{H}, \mathrm{C}_{6} \mathrm{H}_{4}\right), 6.86$ and $7.00\left(\mathrm{~d}, J=8.7 \mathrm{~Hz}, 2 \mathrm{H}, \mathrm{C}_{6} \mathrm{H}_{4}\right), 8.20$ and $8.22(\mathrm{~s}, 1 \mathrm{H}, \mathrm{OH}) .{ }^{13} \mathrm{C}-\mathrm{NMR}\left(75.4 \mathrm{MHz}\right.$, acetone- $\left.\mathrm{d}_{6}\right): \delta 15.1$ and $15.2\left(\mathrm{CH}_{3}\right), 22.8$ and $23.0\left(\mathrm{CH}_{2}\right), 39.1$ and $40.1\left(\mathrm{CH}_{2}\right), 39.6$ and $40.9\left(\mathrm{CH}_{2}\right), 63.4$ and 64.2 $\left(\mathrm{CH}_{2} \mathrm{O}\right), 69.0$ and $69.2\left(2 \mathrm{CH}, \mathrm{C}_{5} \mathrm{H}_{4}\right), 70.3$ and $70.4(5 \mathrm{CH}, \mathrm{Cp}), 70.5$ and $70.6\left(2 \mathrm{CH}, \mathrm{C}_{5} \mathrm{H}_{4}\right), 89.6$ and $90.3\left(\mathrm{C}, \mathrm{C}_{5} \mathrm{H}_{4}\right), 116.6$ and $116.7\left(2 \mathrm{CH}, \mathrm{C}_{6} \mathrm{H}_{4}\right), 131.2$ and $131.6\left(2 \mathrm{CH}, \mathrm{C}_{6} \mathrm{H}_{4}\right), 137.2(\mathrm{C}), 140.3(\mathrm{C})$, $142.4(\mathrm{C}), 157.5(\mathrm{C})$. IR $\left(\mathrm{KBr}, v \mathrm{~cm}^{-1}\right)$ : $3418(\mathrm{OH}), 2959,2870\left(\mathrm{CH}_{2}, \mathrm{CH}_{3}\right)$. HRMS (CI, $\mathrm{CH}_{4}$, $\mathrm{C}_{23} \mathrm{H}_{27} \mathrm{FeO}_{2}:[\mathrm{M}+\mathrm{H}]^{+}$) calcd: 391.1361, found: 391.1359. Anal. Calcd for $\mathrm{C}_{23} \mathrm{H}_{26} \mathrm{FeO}_{2}: \mathrm{C}, 70.77 ; \mathrm{H}$, 6.71. Found: C, 70.49; H, 6.75 .

2-Ferrocenyl-2-(4-hydroxyphenyl)-pentan-3-one (9). Zinc powder (2.35 g, $36 \mathrm{mmol})$, titanium tetrachloride $(2.64 \mathrm{~mL}, 24 \mathrm{mmol})$, chloroacetylferrocene $(1.58 \mathrm{~g}, 6.0 \mathrm{mmol}), p$-hydroxypropiophenone ( $0.90 \mathrm{~g}, 6.0 \mathrm{mmol})$. After purification by HPLC (acetonitrile/water 80/20), and recrystallization from pentane/diethylether mixture, 9 was obtained as orange crystals (0.62 g, 29\% yield). ${ }^{1} \mathrm{H}-\mathrm{NMR}$ (300 $\mathrm{MHz}$, acetone- $\left.\mathrm{d}_{6}\right): \delta 0.97\left(\mathrm{t}, J=7.5 \mathrm{~Hz}, 3 \mathrm{H}, \mathrm{CH}_{3}\right), 1.77\left(\mathrm{~s}, 3 \mathrm{H}, \mathrm{CH}_{3}\right), 2.32-2.38\left(\mathrm{~m}, 2 \mathrm{H}, \mathrm{CH}_{2}\right), 4.08(\mathrm{~s}$, 
$\left.1 \mathrm{H}, \mathrm{C}_{5} \mathrm{H}_{4}\right), 4.15(\mathrm{~s}, 5 \mathrm{H}, \mathrm{Cp}), 4.27\left(\mathrm{~s}, 3 \mathrm{H}, \mathrm{C}_{5} \mathrm{H}_{4}\right), 6.79\left(\mathrm{~d}, J=8.4 \mathrm{~Hz}, 2 \mathrm{H}, \mathrm{C}_{6} \mathrm{H}_{4}\right), 6.99(\mathrm{~d}, J=8.4 \mathrm{~Hz}$, $\left.2 \mathrm{H}, \mathrm{C}_{6} \mathrm{H}_{4}\right), 8.30(\mathrm{~s}, 1 \mathrm{H}, \mathrm{OH}) .{ }^{13} \mathrm{C}-\mathrm{NMR}\left(75.4 \mathrm{MHz}\right.$, acetone- $\left.d_{6}\right): \delta 9.4\left(\mathrm{CH}_{3}\right), 26.4\left(\mathrm{CH}_{3}\right), 33.5\left(\mathrm{CH}_{2}\right)$, $56.5(\mathrm{C}), 68.2\left(\mathrm{CH}, \mathrm{C}_{5} \mathrm{H}_{4}\right), 68.3\left(\mathrm{CH}, \mathrm{C}_{5} \mathrm{H}_{4}\right), 68.9\left(\mathrm{CH}, \mathrm{C}_{5} \mathrm{H}_{4}\right), 69.0\left(\mathrm{CH}, \mathrm{C}_{5} \mathrm{H}_{4}\right), 69.7(5 \mathrm{CH}, \mathrm{Cp}), 92.5$ $\left(\mathrm{C}, \mathrm{C}_{5} \mathrm{H}_{4}\right), 115.8\left(2 \mathrm{CH}, \mathrm{C}_{6} \mathrm{H}_{4}\right), 129.0\left(2 \mathrm{CH}, \mathrm{C}_{6} \mathrm{H}_{4}\right), 137.1\left(\mathrm{C}, \mathrm{C}_{6} \mathrm{H}_{4}\right), 156.9\left(\mathrm{C}, \mathrm{C}_{6} \mathrm{H}_{4}\right), 211.4(\mathrm{CO})$. IR $\left(\mathrm{KBr}, v \mathrm{~cm}^{-1}\right)$ : $3342(\mathrm{OH}), 3097,2986,2937\left(\mathrm{CH}_{2}, \mathrm{CH}_{3}\right), 1687(\mathrm{CO}) . \mathrm{MS}\left(\mathrm{CI}, \mathrm{CH}_{4}\right) \mathrm{m} / z: 363[\mathrm{M}+\mathrm{H}]^{+}$, $362[\mathrm{M}]^{+}$, $391\left[\mathrm{M}+\mathrm{C}_{2} \mathrm{H}_{5}\right]^{+}, 305,269$, 186. Anal. Calcd for $\mathrm{C}_{21} \mathrm{H}_{22} \mathrm{FeO}_{2}$ : C, 69.62; H, 6.12. Found: C, $69.37 ; \mathrm{H}, 6.14$.

2-Ferrocenyl-1,1-bis-(4-hydroxyphenyl)-prop-1-ene (10). Zinc powder (3.56 g, $54.5 \mathrm{mmol})$, titanium tetrachloride (3.2 mL, $29 \mathrm{mmol})$, acetylferrocene $(2 \mathrm{~g}, 8.9 \mathrm{mmol}), 4,4$ '-dihydroxybenzophenone $(1.9 \mathrm{~g}$, $8.9 \mathrm{mmol})$. After chromatography, recrystallization from a pentane/diethylether mixture, $\mathbf{1 0}$ was obtained as bright yellow crystals $\left(3.26\right.$ g, 90\% yield). m.p. $94-95{ }^{\circ} \mathrm{C} ;{ }^{1} \mathrm{H}-\mathrm{NMR}\left(300 \mathrm{MHz}\right.$, acetone- $\left.d_{6}\right)$ : $\delta 2.20\left(\mathrm{~s}, 3 \mathrm{H}, \mathrm{CH}_{3}\right), 3.97\left(\mathrm{t}, J=1.9 \mathrm{~Hz}, 2 \mathrm{H}, \mathrm{C}_{5} \mathrm{H}_{4}\right), 4.09\left(\mathrm{t}, J=1.9 \mathrm{~Hz}, 2 \mathrm{H}, \mathrm{C}_{5} \mathrm{H}_{4}\right), 4.17(\mathrm{~s}, 5 \mathrm{H}, \mathrm{Cp})$, $6.72\left(\mathrm{~d}, J=8.5 \mathrm{~Hz}, 2 \mathrm{H}, \mathrm{C}_{6} \mathrm{H}_{4}\right), 6.84\left(\mathrm{~d}, J=8.5 \mathrm{~Hz}, 2 \mathrm{H}, \mathrm{C}_{6} \mathrm{H}_{4}\right), 6.85\left(\mathrm{~d}, J=8.5 \mathrm{~Hz}, 2 \mathrm{H}, \mathrm{C}_{6} \mathrm{H}_{4}\right), 7.06(\mathrm{~d}$, $\left.J=8.5 \mathrm{~Hz}, 2 \mathrm{H}, \mathrm{C}_{6} \mathrm{H}_{4}\right), 8.22(\mathrm{~s}, 1 \mathrm{H}, \mathrm{OH}), 8.29(\mathrm{~s}, 1 \mathrm{H}, \mathrm{OH}) .{ }^{13} \mathrm{C}-\mathrm{NMR}\left(75.4 \mathrm{MHz}\right.$, acetone- $\left.d_{6}\right): \delta 22.2$ $\left(\mathrm{CH}_{3}\right), 68.5\left(2 \mathrm{CH}, \mathrm{C}_{5} \mathrm{H}_{4}\right), 69.7(5 \mathrm{CH}, \mathrm{Cp}), 69.9\left(2 \mathrm{CH}, \mathrm{C}_{5} \mathrm{H}_{4}\right), 89.0\left(\mathrm{C}, \mathrm{C}_{5} \mathrm{H}_{4}\right), 115.6\left(2 \times 2 \mathrm{CH}, \mathrm{C}_{6} \mathrm{H}_{4}\right)$, $129.8(\mathrm{C}), 131.8\left(2 \mathrm{CH}, \mathrm{C}_{6} \mathrm{H}_{4}\right), 132.2\left(2 \mathrm{CH}, \mathrm{C}_{6} \mathrm{H}_{4}\right), 136.9$ (C), 137.0 (C), 138.8 (C), 156.7 (2C). IR $\left(\mathrm{KBr}, v \mathrm{~cm}^{-1}\right): 3378(\mathrm{OH})$. MS (EI, $\left.70 \mathrm{eV}\right) \mathrm{m} / z: 410[\mathrm{M}]^{+}, 395[\mathrm{M}-\mathrm{Me}]^{+}, 345$ [M-Cp] $^{+}, 121[\mathrm{CpFe}]^{+}$. HRMS (FAB, $\mathrm{C}_{25} \mathrm{H}_{22} \mathrm{FeO}_{2}:[\mathrm{M}]^{+}$) calcd: 410.0969, found: 410.0986. Anal. Calcd for $\mathrm{C}_{25} \mathrm{H}_{22} \mathrm{FeO}_{2} \cdot \mathrm{H}_{2} \mathrm{O}$ : C, 70.10; H, 5.64. Found: C, 70.45; H, 5.55.

3-Ferrocenyl-4-(4-methoxyphenyl)-hex-3-ene (13). Zinc powder (1.82 g, $27.9 \mathrm{mmol})$, titanium tetrachloride $(2.04 \mathrm{~mL}, 18.6 \mathrm{mmol})$, ferrocenyl ethyl ketone $(1.13 \mathrm{~g}, 4.65 \mathrm{mmol})$, p-methoxypropiophenone (0.76 g, $4.6 \mathrm{mmol}$ ). Chromatography then HPLC (acetonitrile/water 70/30). Recrystallization from EtOH gave 13 as orange crystals $(0.57 \mathrm{~g}, 33 \%$ yield) consisting of a mixture of $Z$ and $E$ isomers (71/29). ${ }^{1} \mathrm{H}-\mathrm{NMR}\left(300 \mathrm{MHz}, \mathrm{CDCl}_{3}\right): \delta 0.94\left(\mathrm{t}, J=7.4 \mathrm{~Hz}, 3 \mathrm{H}, \mathrm{CH}_{3}\right), 1.27(\mathrm{t}, J=7.4 \mathrm{~Hz}$, $\left.3 \mathrm{H}, \mathrm{CH}_{3}\right), 2.30$ and 2.43 (q, $J=7.4 \mathrm{~Hz}, 2 \mathrm{H}, \mathrm{CH}_{2}$ ), 2.56 and 2.63 (q, $J=7.4 \mathrm{~Hz}, 2 \mathrm{H}, \mathrm{CH}_{2}$ ), 3.72 and 4.26 $\left(\mathrm{s}, 2 \mathrm{H}, \mathrm{C}_{5} \mathrm{H}_{4}\right), 3.83$ and $3.85\left(\mathrm{~s}, 3 \mathrm{H}, \mathrm{OCH}_{3}\right), 3.99$ and $4.37\left(\mathrm{~s}, 2 \mathrm{H}, \mathrm{C}_{5} \mathrm{H}_{4}\right), 4.05$ and $4.16(\mathrm{~s}, 5 \mathrm{H}, \mathrm{Cp})$, 6.86 and $6.91\left(\mathrm{~d}, J=8.6 \mathrm{~Hz}, 2 \mathrm{H}, \mathrm{C}_{6} \mathrm{H}_{4}\right), 6.97$ and $7.07\left(\mathrm{~d}, J=8.6 \mathrm{~Hz}, 2 \mathrm{H}, \mathrm{C}_{6} \mathrm{H}_{4}\right) .{ }^{13} \mathrm{C}-\mathrm{NMR}(75.4$ $\left.\mathrm{MHz}, \mathrm{CDCl}_{3}\right): \delta 12.8$ and $13.0\left(\mathrm{CH}_{3}\right), 15.2$ and $15.9\left(\mathrm{CH}_{3}\right), 26.5$ and $28.3\left(\mathrm{CH}_{2}\right), 28.7$ and $29.3\left(\mathrm{CH}_{2}\right)$, $55.1\left(\mathrm{OCH}_{3}\right), 67.5$ and $67.7\left(2 \mathrm{CH}, \mathrm{C}_{5} \mathrm{H}_{4}\right), 68.7$ and $68.8\left(2 \mathrm{CH}, \mathrm{C}_{5} \mathrm{H}_{4}\right), 68.9$ and $69.0(5 \mathrm{CH}, \mathrm{Cp}), 87.5$ and $87.7\left(\mathrm{C}, \mathrm{C}_{5} \mathrm{H}_{4}\right), 113.4$ and $113.5\left(2 \mathrm{CH}, \mathrm{C}_{6} \mathrm{H}_{4}\right), 129.7$ and $130.1\left(2 \mathrm{CH}, \mathrm{C}_{6} \mathrm{H}_{4}\right), 133.0$ and $133.3(\mathrm{C})$, 136.7 and 136.9 (C), 137.9 and 139.8 (C), 157.7 and 157.9 (C). IR (KBr, $\left.v \mathrm{~cm}^{-1}\right): 3094,3062,2929$, $2871\left(\mathrm{CH}_{2}, \mathrm{CH}_{3}\right)$. MS (EI, $\left.70 \mathrm{eV}\right) \mathrm{m} / z: 374[\mathrm{M}]^{+}, 345,309[\mathrm{M}-\mathrm{Cp}]^{+}, 293,121[\mathrm{CpFe}]^{+}$. Anal. Calcd for $\mathrm{C}_{23} \mathrm{H}_{26} \mathrm{FeO}$ : C, 73.80; H, 7.00. Found: C, 73.44; H, 6.94.

Ethyl 3-ene-3-ferrocenyl-4,4-bis-(4-hydroxyphenyl)-butanoate (17b). The general procedure has been followed. Zinc powder $(7.84 \mathrm{~g}, 120 \mathrm{mmol})$, titanium tetrachloride $(8.8 \mathrm{~mL}, 80 \mathrm{mmol})$, ethyl 3-ferrocenyl-3-oxo-propanoate (6 g, $20 \mathrm{mmol})$, 4,4'-dihydroxybenzophenone (8.6 g, $40 \mathrm{mmol})$. After chromatography, recrystallization from EtOH/water, $\mathbf{1 7 b}$ was obtained as orange crystals (3.84 g, 40\% yield). ${ }^{1} \mathrm{H}-\mathrm{NMR}$ (acetone- $d_{6}$ ): $\delta 1.23\left(\mathrm{t}, J=7.2 \mathrm{~Hz}, 3 \mathrm{H}, \mathrm{CH}_{3}\right), 3.65\left(\mathrm{~s}, 2 \mathrm{H}, \mathrm{CH}_{2}\right), 3.93(\mathrm{t}, J=2.0 \mathrm{~Hz}$, $\left.2 \mathrm{H}, \mathrm{C}_{5} \mathrm{H}_{4}\right), 4.09$ (q, $\left.J=7.2 \mathrm{~Hz}, 2 \mathrm{H}, \mathrm{CH}_{2} \mathrm{O}\right), 4.11$ (t, $\left.J=2.0 \mathrm{~Hz}, 2 \mathrm{H}, \mathrm{C}_{5} \mathrm{H}_{4}\right), 4.17(\mathrm{~s}, 5 \mathrm{H}, \mathrm{Cp}), 6.76$ (d, 
$\left.J=8.7 \mathrm{~Hz}, 2 \mathrm{H}, \mathrm{C}_{6} \mathrm{H}_{4}\right), 6.83\left(\mathrm{~d}, J=8.7 \mathrm{~Hz}, 2 \mathrm{H}, \mathrm{C}_{6} \mathrm{H}_{4}\right), 6.97\left(\mathrm{~d}, J=8.7 \mathrm{~Hz}, 2 \mathrm{H}, \mathrm{C}_{6} \mathrm{H}_{4}\right), 7.10(\mathrm{~d}, J=8.7 \mathrm{~Hz}$, $\left.2 \mathrm{H}, \mathrm{C}_{6} \mathrm{H}_{4}\right), 8.31(\mathrm{~s}, 1 \mathrm{H}, \mathrm{OH}), 8.33(\mathrm{~s}, 1 \mathrm{H}, \mathrm{OH}) .{ }^{13} \mathrm{C}-\mathrm{NMR}$ (acetone- $\left.d_{6}\right): \delta 15.3\left(\mathrm{CH}_{3}\right), 44.1\left(\mathrm{CH}_{2}\right)$, $61.5\left(\mathrm{CH}_{2} \mathrm{O}\right), 69.5\left(2 \mathrm{CH}, \mathrm{C}_{5} \mathrm{H}_{4}\right), 70.6(5 \mathrm{CH}, \mathrm{Cp}), 70.7\left(2 \mathrm{CH}, \mathrm{C}_{5} \mathrm{H}_{4}\right), 88.8\left(\mathrm{C}, \mathrm{C}_{5} \mathrm{H}_{4}\right), 116.5(2 \mathrm{CH}$, $\left.\mathrm{C}_{6} \mathrm{H}_{4}\right), 116.6\left(2 \mathrm{CH}, \mathrm{C}_{6} \mathrm{H}_{4}\right), 128.9(\mathrm{C}), 131.8\left(2 \mathrm{CH}, \mathrm{C}_{6} \mathrm{H}_{4}\right), 132.4\left(2 \mathrm{CH}, \mathrm{C}_{6} \mathrm{H}_{4}\right), 137.2(\mathrm{C}), 137.3(\mathrm{C})$, 142.8 (C), 157.7 (2C), 173.2 (CO). IR (KBr, $\left.v \mathrm{~cm}^{-1}\right)$ : $3361(\mathrm{OH}), 2933,2986,3035\left(\mathrm{CH}_{2}, \mathrm{CH}_{3}\right), 1682$ (CO). MS (CI, $\left.\mathrm{NH}_{3}\right) \mathrm{m} / z: 483[\mathrm{M}+\mathrm{H}]^{+}, 500\left[\mathrm{M}+\mathrm{NH}_{4}\right]^{+}$. HRMS (CI, $\left.\mathrm{NH}_{3}, \mathrm{C}_{28} \mathrm{H}_{27} \mathrm{FeO}_{4}:[\mathrm{M}+\mathrm{H}]^{+}\right)$calcd: 483.1259, found: 483.1265. Anal. Calcd for $\mathrm{C}_{28} \mathrm{H}_{26} \mathrm{FeO}_{4}$ : C, 69.72; H, 5.43. Found: C, 69.63; H, 5.45.

\subsection{X-ray Crystallography}

Suitable crystals of $\mathbf{5 b}, \mathbf{9}, \mathbf{1 4}$ and $\mathbf{1 7 b}$ were obtained from acetonitrile or acetone:hexane (for $\mathbf{5 b}$ ). Crystallographic data are given in Table S1 in the Supporting Information. These have also been deposited at the Cambridge Crystallographic Data Centre: 5b (1007086), 9 (1007087) and 17b (1007088). Molecule 14 exhibited a minor crystallographic disorder giving rise to an apparent mirror plane so, although the structure is unambiguously established, we prefer not to quote precise bond lengths and angles. Unit cell data are listed in reference [39].

\section{Conclusions}

It has been shown here that the ferrocenyl-diaryl-ethylene series is not the only one active against hormone-independent breast cancer cells. The second $p$-hydroxyphenyl group can be replaced by an alkyl group, but in this case the presence of a hydroxyethyl group is necessary for good activity. In fact, the alkyl group seems not to play an essential role except for a decrease in activity as the chain lengthens. As a result of these factors, 3-ferrocenyl-4-(4-hydroxyphenyl)-1-hydroxy-pent-3-ene, 5a, bearing a methyl group adjacent to the phenol substituent, has the best value of the series $\left(\mathrm{IC}_{50}=0.14 \mu \mathrm{M}\right)$. Unfortunately, at present the yields are low for the preparation of these promising hydroxylated species (10\%-16\% for the McMurry coupling), and need to be improved.

Even though one starts from relatively inexpensive, commercially available ketones and easily synthesized chloropropionyl-ferrocene, 6, (Friedel-Crafts), and the McMurry second step led to the cross-coupled product possessing the double bond and the hydroxyethyl substituent in a one-pot process, nevertheless, final separation of the desired product is difficult. Modified reaction conditions, together with an enhanced understanding of the mechanism (such as the importance of hydride transfer) may lead to improved yields. It may be worthwhile to attempt the McMurry reaction starting directly from the keto-alcohol, but pinacolone by-products would of course diminish the overall yields, and alternative routes need to be developed. Other new compounds bearing the [ferrocenyl-(hydroxyethyl)-ene-phenol] motif are under active investigation with the aim of elucidating the role of the hydroxyethyl group in promoting cytotoxic activity.

\section{Supplementary Materials}

Supplementary materials can be accessed at: http://www.mdpi.com/1420-3049/19/7/10350/s1. 


\section{Acknowledgments}

The authors wish to thank P. Herson and J. Vaissermann for three crystal structure determinations and T. Cresteil for $\mathrm{IC}_{50}$ determinations. We thank Anh N'Guyen for full discussions. K.K.'s stay in Paris was supported through an European Community Marie Curie Fellowship (HMPT-CT-200000186). We thank the Agence Nationale de la Recherche for financial support (ANR 2010 BLAN 7061 blanc "Mecaferrol") and the Ministère des Affaires Etrangères for a doctoral fellowship (M.G.).

\section{Author Contributions}

Syntheses: PP, MG, KK. Research concept: GJ, PP, ST, KK. X-ray structure: HMB. Writing and discussions: PP, MJM, GJ, ST.

\section{Conflicts of Interest}

The authors declare no conflict of interest.

\section{References and Notes}

1. Jaouen, G.; Top, S. The Ferrocifen family as Potent and Selective Antitumor Compounds: Mechanisms of Action. In Advances in Organometallic Chemistry and Catalysis; Pombeiro, A.J.L., Ed.; Wiley: Hoboken, NJ, USA, 2014; pp. 563-580.

2. Barry, N.P.E.; Sadler, P.J. Exploration of the medical periodic table: Towards new targets. Chem. Commun. 2013, 49, 5106-5131.

3. Bertrand, B.; Casini, A. A golden future in medicinal inorganic chemistry: The promise of anticancer gold organometallic compounds. Dalton Trans. 2014, 43, 4209-4219.

4. Braga, S.S.; Silva, A.M.S. A new age for iron: Antitumoral ferrocenes. Organometallics 2013, 32 , 5626-5639.

5. Hillard, E.A.; Jaouen, G. Bioorganometallics: Future trends in drug discovery, analytical chemistry and catalysis. Organometallics 2011, 30, 20-27.

6. Hillard, E.A.; Vessières, A.; Jaouen, G. Topics in organometallic chemistry. In Medicinal Organometallic Chemistry; Jaouen, G., Metzler-Nolte, N, Eds.; Springer-Verlag: Heidelberg, Germany, 2010; Volume 32, p. 81.

7. Ornelas, C. Application of ferrocene and its derivatives in cancer research. New J. Chem. 2011, 35, 1973-1985.

8. Top, S.; Vessières, A.; Leclercq, G.; Quivy, J.; Tang, J.; Vaissermann, J.; Huché, M.; Jaouen, G. Synthesis, biochemical properties and molecular modeling studies of organometallic specific estrogen receptor modulators (SERMs), the ferrocifens and hydroxyferrocifens: Evidence for an antiproliferative effect of hydroxyferrocifens on both hormone-dependent and hormoneindependent breast cancer cell lines. Chem. Eur. J. 2003, 9, 5223-5236.

9. Top, S.; Tang, J.; Vessières, A.; Carrez, D.; Provot, C.; Jaouen, G. Ferrocenyl hydroxytamoxifen: A prototype for a new range of estradiol receptor site-directed cytotoxics. Chem. Commun. 1996, 8, 955-956. 
10. Vessières, A.; Top, S.; Pigeon, P.; Hillard, E.A.; Boubeker, L.; Spera, D.; Jaouen, G. Modification of the estrogenic properties of diphenols by the incorporation of ferrocene. Generation of anti-proliferative effects in vivo. J. Med. Chem. 2005, 48, 3937-3940.

11. O’Regan, R.M.; Cisneros, A.; England, G.M.; MacGregor, J.I.; Muenzner, H.D.; Assikis, V.J.; Bilimoria, M.M.; Piette, M.; Dragan, Y.P.; Pitot, H.C.; et al. Effects of the antiestrogens tamoxifen, toremifene, and ICI 182,780 on endometrial cancer growth. J. Natl. Cancer Inst. 1998, 90, 1552-1558.

12. Valavaara, R.; Pyrhönen, S.; Heikkinen, M.; Rissanen, P.; Blanco, G.; Thölix, E.; Nordman, E.; Taskinen, P.; Holsti, L.; Hajba, A. Toremifene, a new antiestrogenic compound, for treatment of advanced breast cancer. Phase II study. J. Cancer Clin. Oncol. 1988, 24, 785-790.

13. Gundersen, S. Toremifene, a new antiestrogenic compound in the treatment of metastatic mammary cancer. A phase II study. J. Steroid Biochem. 1990, 36, 233-234.

14. Modig, H.; Borgström, S.; Nilsson, I.; Westman, G. Phase II clinical study of toremifene in patients with metastatic breast cancer. Preliminary communication. J. Steroid Biochem. 1990, 36, 235-236.

15. Milla-Santos, A.; Milla, L.; Rallo, L.; Solano, V. Phase III randomized trial of toremifene vs. tamoxifen in hormonodependant advanced breast cancer. Breast Cancer Res. Treat. 2001, 65, 119-124.

16. Baur, J.A.; Pearson, K.J.; Price, N.L.; Jamieson, H.A.; Lerin, C.; Kalra, A.; Prabhu, V.V.; Allard, J.S.; Lopez-Lluch, G.; Lewis, K.; et al. Resveratrol improves health and survival of mice on a high-calorie diet. Nature 2006, 444, 337-342.

17. Raghow, S.; Hooshdaran, M.Z.; Katiyar, S.; Steiner, M.S. Toremifene prevents prostate cancer in the transgenic adenocarcinoma of mouse prostate model. Cancer Res. 2002, 62, 1370-1376.

18. Smith, M.R.; Malkowicz, S.B.; Chu, F.; Forrest, J.; Price, D.; Sieber, P.; Barnette, K.G.; Rodriguez, D.; Steiner, M.S. Toremifene increases bone mineral density in men receiving androgen deprivation therapy for prostate cancer: Interim analysis of a multicenter phase 3 clinical study. J. Urol. 2008, 179, 152-155.

19. Buriez, O.; Heldt, J.M.; Labbé, E.; Vessières, A.; Jaouen, G.; Amatore, C. Reactivity and antiproliferative activity of ferrocenyl-tamoxifen adducts with cyclodextrins against hormoneindependent breast-cancer cell lines. Chem.-Eur. J. 2008, 14, 8195-8203.

20. Van Lipzig, M.M.H.; ter Laak, A.M.; Jongejan, A.; Vermeulen, N.P.E.; Wamelink, M.; Geerke, D.; Meerman, J.H.N. Prediction of ligand binding affinity and orientation of xenoestrogens to the estrogen receptor by molecular dynamics simulations and the linear interaction energy method. J. Med. Chem. 2004, 47, 1018-1030.

21. Giusti, R.M.; Iwamoto, K.; Hatch, E.E. Diethylstilbestrol revisited: A review of the long-term health effects. Ann. Intern. Med. 1995, 122, 778-788.

22. Schrager, S.; Potter, B.E. Diethylstilbestrol exposure. Am. Fam. Physician 2004, 69, 2395-2400.

23. Jaouen, G.; Top, S.; Vessières, A.; Sayer, B.G.; Frampton, C.S.; McGlinchey, M. Molecular recognition using bioorganometallic probes: NMR, X-ray crystallographic, and molecular modeling study of the conformations of chromium tricarbonyl derivatives of hexestrol and their relevance to estradiol-receptor binding. J. Organomet. 1992, 11, 4061-4068. 
24. Tondu, S.; Top, S.; Vessières, A.; Jaouen, G. The use of tricarbonyl chromium hexestrol derivatives in the detection of oestradiol receptor sites J. Chem. Soc. Chem. Commun. 1985, 326-328.

25. Gruselle, M.; Malezieux, B.; Sokolov, V.I.; Troitskaya, L.L. Enantioselective synthesis of ferrocene analogs of hexestrol and estradiol; recognition towards estradiol receptors. Inorganica. Chim. Acta 1994, 222, 51-61.

26. Hillard, E.A.; Vessières, A.; Top, S.; Pigeon, P.; Kowalski, K.; Huché, M.; Jaouen, G. Organometallic diphenols: The importance of the organometallic moiety on the expression of a cytotoxic effect on breast cancer cells. J. Organomet. Chem. 2007, 692, 1315-1326.

27. Elecko, P.; Foltinova, P.; Salisova, M.; Solcaniova, E.; Toma, S. Synthesis, proton magnetic resonance spectra, and biological activity of haloacylferrocenes. Chemicke. Zvesti. 1974, 28, 94-99.

28. Ephritikhine, M. A new look at the McMurry reaction. Chem. Commun. 1998, 23, 2549-2554

29. Görmen, M.; Pigeon, P.; Hillard, E.A.; Vessières, A.; Huché, M.; Richard, M.-A.; McGlinchey, M.J.; Top, S.; Jaouen, G. Synthesis and antiproliferative effects of [3]ferrocenophane transposition products and pinacols obtained from McMurry cross-coupling reactions. Organometallics 2012, $31,5856-5866$.

30. Tan, Y.L.K.; Pigeon, P.; Hillard, E.A.; Top, S.; Plamont, M.-A.; Vessières, A.; McGlinchey, M.J.; Müller-Bunz, H.; Jaouen, G. Synthesis, oxidation chemistry and cytotoxicity studies on ferrocene derivatives of diethylstilbestrol. Dalton Trans. 2009, 10871-10881.

31. Schlögl, K.; Egger, H. Syntheses and reactions of ferrocenylacetylenes. Monatsh. Chem. 1963, 94, 376-392.

32. Ortin, Y.; Grealis, J.; Scully, C.; Müller-Bunz, H.; Manning, A.R.; McGlinchey, M.J. McMurry reactions of $\left(\eta^{5}\right.$-acetylcyclopentadienyl)cobalt $\left(\eta^{4}\right.$-tetraphenylcyclo-butadiene) with benzo-phenone: Ketone couplings and a pinacol-pinacolone rearrangement. J. Organomet. Chem. 2004, 689, 4683-4690.

33. Baddeley, G. Modern aspects of the Friedel-Crafts reaction. Quart. Rev. 1954, 8, 355-379.

34. Hillard, E.A.; Pigeon, P.; Vessières, A.; Amatore, C.; Jaouen, G. The influence of phenolic hydroxy substitution on the electron transfer and anti-cancer properties of compounds based on the 2-ferrocenyl-1-phenyl-but-1-ene motif. Dalton Trans. 2007, 43, 5073-5081.

35. Hillard, E.A.; Vessières, A.; le Bideau, F.; Plazuk, D.; Spera, D.; Huché, M.; Jaouen, G. A series of unconjugated ferrocenyl phenols: Prospects as anticancer agents. Chem. Med. Chem. 2006, 1, $551-559$.

36. Heilmann, J.B.; Hillard, E.A.; Plamont, M.-A.; Pigeon, P.; Bolte, M.; Jaouen, G.; Vessières, A. Ferrocenyl compounds possessing protected phenol and thiophenol groups: Synthesis, X-ray structure, and in vitro biological effects against breast cancer. J. Organomet. Chem. 2008, 693, 1716-1722.

37. Görmen, M.; Pigeon, P.; Top, S.; Vessières, A.; Plamont, M.-A.; Hillard, E.A.; Jaouen, G. Facile synthesis and strong antiproliferative activity of disubstituted diphenylmethylidenyl[3] ferrocenophanes on breast and prostate cancer cell lines. Med. Chem. Commun. 2010, 1, $149-151$. 
38. Görmen, M.; Plażuk, D.; Pigeon, P.; Hillard, E.A.; Plamont, M.-A.; Top, S.; Vessières, A.; Jaouen, G. Comparative toxicity of [3]ferrocenophane and ferrocene moieties on breast cancer cells. Tetrahedron Lett. 2010, 51, 118-120.

39. X-ray data for 14: The unit cell is orthogonal with $\mathrm{a}=9.8552(7) \AA, \mathrm{b}=9.7478(8) \AA$, $\mathrm{c}=18.523(2) \AA, \alpha=\beta=\gamma=90^{\circ}, \mathrm{V}=1729.5(2) \AA^{3}$, and the space group is $P$ nma (\#62).

Sample Availability: Samples of the compounds $\mathbf{5 a}-\mathbf{c}$ are available from the authors.

(C) 2014 by the authors; licensee MDPI, Basel, Switzerland. This article is an open access article distributed under the terms and conditions of the Creative Commons Attribution license (http://creativecommons.org/licenses/by/3.0/). 